Article

\title{
The Direct Involvement of Dark-Induced Tic55 Protein in Chlorophyll Catabolism and Its Indirect Role in the MYB108-NAC Signaling Pathway during Leaf Senescence in Arabidopsis thaliana
}

\author{
Ming-Lun Chou ${ }^{1,+}(\mathbb{D})$, Wan-Yu Liao ${ }^{2,+}{ }^{+}$Wan-Chen Wei ${ }^{3}$, Althea Yi-Shan Li ${ }^{1}$, Ching-Ying Chu ${ }^{1}$, \\ Chia-Ling $\mathrm{Wu}^{1}{ }^{1}$, Chun-Lin Liu ${ }^{4}$, Ting-Han Fu ${ }^{5}$ and Lee-Fong Lin ${ }^{1, *}$ \\ 1 Department of Life Sciences, Tzu Chi University, Hualien 97004, Taiwan; \\ mlchou1015@gms.tcu.edu.tw (M.-L.C.); 103711117@gms.tcu.edu.tw (A.Y.-S.L.); \\ 104711126@gms.tcu.edu.tw (C.-Y.C.); 106726102@gms.tcu.edu.tw (C.-L.W.) \\ 2 Institute of Medical Sciences, Tzu Chi University, Hualien 97004, Taiwan; 98751101@gms.tcu.edu.tw \\ 3 Department of Surgery, Cheng-Ching Hospital, Chung-Kang Branch, Taichung 40764, Taiwan; \\ wcwei0125@gmail.com \\ 4 Department of Molecular Biology and Human Genetics, Tzu Chi University, Hualien 97004, Taiwan; \\ kohiyodesuyama@gmail.com \\ 5 Department of Medical Informatics, Tzu Chi University, Hualien 97004, Taiwan; tinghan117@gmail.com \\ * Correspondence: leelin@gms.tcu.edu.tw; Tel.: +886-3-8565301 (ext. 2625); Fax: +886-3-8572526 \\ $\dagger$ These authors contributed equally to this study.
}

Received: 18 May 2018; Accepted: 21 June 2018; Published: 23 June 2018

\begin{abstract}
The chloroplast relies on proteins encoded in the nucleus, synthesized in the cytosol and subsequently transported into chloroplast through the protein complexes Toc and Tic (Translocon at the outer/inner membrane of chloroplasts). A Tic complex member, Tic55, contains a redox-related motif essential for protein import into chloroplasts in peas. However, Tic55 is not crucial for protein import in Arabidopsis. Here, a tic55-II-knockout mutant of Arabidopsis thaliana was characterized for Tic55 localization, its relationship with other translocon proteins, and its association with plant leaf senescence when compared to the wild type. Individually darkened leaves (IDLs) obtained through dark-induced leaf senescence were used to demonstrate chlorophyll breakdown and its relationship with plant senescence in the tic55-II-knockout mutant. The IDLs of the tic55-II-knockout mutant contained higher chlorophyll concentrations than those of the wild type. Our microarray analysis of IDLs during leaf senescence identified seven senescence-associated genes (SAGs) that were downregulated in the tic55-II-knockout mutant: ASP3, APG7, DIN2, DIN11, SAG12, SAG13, and YLS9. Real-time quantitative PCR confirmed the reliability of microarray analysis by showing the same expression patterns with those of the microarray data. Thus, Tic55 functions in dark-induced aging in A. thaliana by indirectly regulating downstream SAGs expression. In addition, the expression of four NAC genes, including ANAC003, ANAC010, ANAC042, and ANAC075 of IDL treated tic55-II-knockout mutant appeared to be downregulated. Yeast one hybrid assay revealed that only ANAC003 promoter region can be bound by MYB108, suggesting that a MYB-NAC regulatory network is involved in dark-stressed senescence.
\end{abstract}

Keywords: Tic55 proteins of chloroplasts; dark-induced leaf senescence; MYB108; ANAC proteins

\section{Introduction}

The chloroplast is mainly composed of proteins encoded by the nuclear genome and synthesized as precursor proteins (preproteins) in the cytosol. During the translocation of precursor proteins, 
several subcomponents of the complex function as the channel/motor complex components Tic110, Tic40, cpHsp70, Hsp90C, and Hsp93/ClpC; redox-regulatory subunits, Tic62, Tic55, and Tic32; and an alternative import channel Tic20/Tic21, Tic22, Tic214, Tic100, and Tic56 [1-9]. The transit peptide of a preprotein is further translocated across the inner membrane through the Tic20/Tic21 channel dependently or independently of Tic110 and translocate across the inner membrane [9-12]. The transit peptide is subsequently cleaved by the stromal processing peptidase (SPP) and the processed mature protein is pulled into the chloroplast's stroma.

In the chloroplasts, photosynthesis relies on the redox reaction. Tic110 itself contains one or two regulatory disulfide bridges [13]. The formation/dissolving of such intramolecular bonds within Tic110 can influence the structure and function of this central Tic component. In addition to the redox state of the thiol system, the $\mathrm{NADP}^{+} / \mathrm{NADPH}$ ratio is a direct measurement of the total stromal redox state. Hirohashi and others [14] demonstrated that the redox state within the chloroplasts may regulate protein targeting. Stengel and others [15] recently demonstrated that the redox state regulates protein import into the chloroplasts and mitochondria. Three redox proteins, Tic55, Tic62, and Tic32, are associated with Tic110; among these, Tic62 can relay the redox status of the stroma to Tic110 [16]. Similar to Tic62, Tic32 dissociates from Tic110 in the presence of NAPDH, suggesting that Tic32 can also be part of a redox-signal transducer [17]. Moreover, Tic55 is associated with Tic62 and Tic32 and contains a redox-related motif essential for protein import into the chloroplasts in peas [8,18-20]. However, redox-motif of Tic55 is essential for its biological function in Arabidopsis remains unclear.

Previous studies showed Tic55 may not be involved in the protein import into chloroplasts like other translocon proteins in Arabidopsis thaliana and rather functions as a hydroxylase of phyllobilins during plant senescence [21,22]. Senescence in green plants is a highly controlled and complicated process. Chlorophyll degradation is the first visible sign of senescence. Arabidopsis and other higher organisms contain four classes of tetrapyrroles and chlorophyll is the most abundant tetrapyrroles that function as photosynetic pigments to harvest light energy and transfer the absorbed energy to the reaction center for the photosynthetic reactions to occur. Leaf yellowing, caused by chlorophyll degradation, is the most apparent indication of senescent leaves. The role of phyllobilin modification, mediated by the hydroxylase activity of Tic55, during chlorophyll breakdown is still not clear [22] Interestingly, chlorophyll degradation can be resulted from a numerous occasions of endogenous and environmental cues. The environmental factors that influence leaf senescence include abiotic and biotic factors. The abiotic influence is attributed to the drought, nutrient limitation, extreme temperature, and oxidative stress, etc. Pathogen infection, on the other hand, is one kind of biotic factors. Nevertheless, leaf senescence can occur prematurely under such unfavorable environmental stresses $[23,24]$. Thus, the net loss of chlorophyll in chloroplasts is the main cause of phenotypic change of senescing leaves from green to yellowing. Several lines of evidence have identified dozens of senescence-related mutants and hundreds of senescence-associated genes ( $S A G s$ ) implicated in hormone signaling, chlorophyll catabolism, and light signaling [25-27]. For example, the famous stay-green pea used by Mendel has been shown to be due to the mutation in the gene encoding pheophorbide $a$ oxygenase [28]. In these mutants, only the chlorophyll degradation pathway is affected. Mutants with single gene mutation usually do not lead to blocking of all aspects of senescence. There are multiple signaling pathways involved in the gene expression during senescence, and it is very likely that a single gene does not control all the signaling pathways implicated in senescence. In an experiment comparing gene expression levels at three stages of leaf development (MG (mature green); S1 (early senescence, no chlorosis) and S2 (mid senescence, $5-15 \%$ chlorosis)), Buchanan-Wollaston and coworkers [29] have identified more than 1400 genes that showed relative changes in expression during leaf development. Although some gene expression may be specific to certain stress stimulation, there is often a large overlap among different stress responses. This notion suggests that common features are possibly involved [30].

The main purpose of plant senescence is to mobilize and recycle. When the leaf is no longer needed by the plant, the senescence process is triggered to relocate all the nutrients from leaves to reproducing 
seeds or to other growing organs. During this process, plant-specific NAC (NAM/ATAF1, 2/CUC2) family of transcription factors (TFs) in controlling the stress responses may play vital roles in plant senescence [31,32]. NAC TFs by far is the largest plant TF families with over 100 members in Arabidopsis for instance [33]. NAC TFs have been related to a variety of stress-associated responses such as drought, high salinity, bacterial and fungal pathogens, and senescence [24,34-38]. Many members of NAC family appear to have overlapping expression patterns and are involved in regulating multiple stress responses, a situation suggesting their common roles in regulation $[24,38,39]$. From the recent structural and functional studies, NAC TFs proteins contain a highly conserved target-specific N-terminal DNA binding domain and a divergent C-terminal domain, which interacts dynamically with other proteins and functions as a transcription regulatory domain (TRD) [40-43]. NAC TFs interact and control other NACs or other TFs to fine-tune the target genes expression, thereby forming a NAC regulatory network to integrate multiple developmental and environmental signals [44,45]. Within this network, NAC, WRKY, and MYB TFs are central key players in regulating transcriptional changes during senescence. Therefore, it appears that leaf senescence is controlled through multiple and cross-linking pathways, many of which are related to stress response signaling [32,38,45-47].

In this study, in order to address whether the redox status of Tic55 in Arabidopsis affects its biological function, a tic55-II-knockout mutant line of Arabidopsis thaliana, SALK_086048, randomly chosen and obtained from the Arabidopsis Biological Resource Center (ABRC), was characterized. The tic55-II-knockout mutant revealed no significant physical differences, and the change in the redox state did not affect the association of this mutant with other translocon proteins. This indicates that Tic55 does not have a crucial role in A. thaliana survival and implies that Tic55 may not function as a redox signal transducer implicated in its biological activities. By contrast, dark-induced leaf senescence experiments (IDLs) [48] have revealed a unique biological function of Tic55 as an aging-related protein in A. thaliana. Chlorophyll concentrations were higher in the tic55-II-knockout mutant than in the wild type (WT). Microarray gene expression analysis of individually darkened leaves (IDLs) during the leaf senescence of A. thaliana revealed 830 transcripts assigned to three main gene ontology (GO) categories, namely biological processes, molecular functions, and cellular components, and 111 subcategories based on TAIR (http:/ / www.arabidopsis.org/help/helppages/go_slim_help.jsp) [49,50]. Seven downregulated senescence-related genes-ASP3 (aspartate aminotransferase 3), APG7 (autophagy-related 7, ubiquitin-like modifier-activating enzyme ATG7), DIN2 (dark inducible 2, beta-glucosidase 30), DIN11 (dark inducible 11, 2-oxoacid-dependent dioxygenase-like protein), SAG12 (senescence-associated gene 12, cysteine protease), SAG13 (senescence-associated gene 13, senescence-associated protein), and YLS9 (yellow-leaf-specific gene 9, protein NDR1/HIN1-like 10)—were selected for further analysis [51-58]. Real-time quantitative reverse-transcription PCR (qRT-PCR) of these seven genes in the Columbia WT and tic55-II-knockout mutant after IDL treatment indicated the reliability of the microarray results. Thus, these seven senescence-associated genes (SAGs), including $S A G 12$ and $S A G 13$ shown previously $[52,53,57]$ as well as in our study, are indeed involved in plant senescence. We also identified from our microarray data four NAC containing proteins, including ANAC003, ANAC010, ANAC042, and ANAC075, whose expressions were downregulated in dark-induced aging in the tic55-II-knockout mutant. Earlier studies have shown that the downstream gene expression of $S A G s$ is possibly associated with the upstream MYB-NAC transcription factors (TFs) controlling signaling pathways [32,59]. The key mechanism of regulation in differential gene expression is that TFs function through sequence-specific binding to the promoters of target genes. Our yeast one-hybrid data revealed that MYB108 indeed interacts with the promoter of $A N A C 003$, indicating MYB-NAC direct regulatory roles in dark-induced senescence in the tic55-II-knockout mutant. We present not only the novel biological function of Tic55 in dark-induced aging in $A$. thaliana, but also this stress-specific regulatory pathway. 


\section{Results and Discussion}

\subsection{Molecular Characterization and Phenotype of T-DNA Insertion Mutant tic55-II}

To assess the biological importance of Tic55 in A. thaliana, tic55 knockout mutant line with T-DNA insertion in tic55 (AT2G24820), named SALK_086048, was obtained from the Arabidopsis Biological Resource Center (ABRC). Both the WT and tic55 knockout mutant plants were grown on Murashige and Skoog (MS) agar with kanamycin, and screening revealed the presence of T-DNA insertion. The T-DNA insertion site in the mutant line was confirmed through genomic PCR, followed by DNA sequencing at the T-DNA/gene junctions. In this knockout mutant, T-DNA disrupted the first exon of Tic55. These mutant lines were further confirmed to be true tic55 knockout plants through RT-PCR and protein gel blot analysis. Although no mutant (08-1, 08-2, or 08-3) showed the presence of the 1.6-kb full-length transcript, it was noted in the WT (Figure 1A). Protein gel blot analysis with a Tic55-specific antibody ( $\alpha$ Tic55) further confirmed the complete absence of Tic55 in the total protein and chloroplast of the knockout line, named tic55-II (Figure 1B). These data corroborate those of Boij et al. [21], who screened and characterized three tic55 knockout mutants, including SALK_086048. We therefore obtained a true tic55 knockout mutant in order to further study the potential biological functions of Tic55 in A. thaliana. Both WT and tic55-II-knockout plants were grown on MS agar and soil to observe abnormal phenotypes. No significant phenotypic differences were observed (Figure 2).

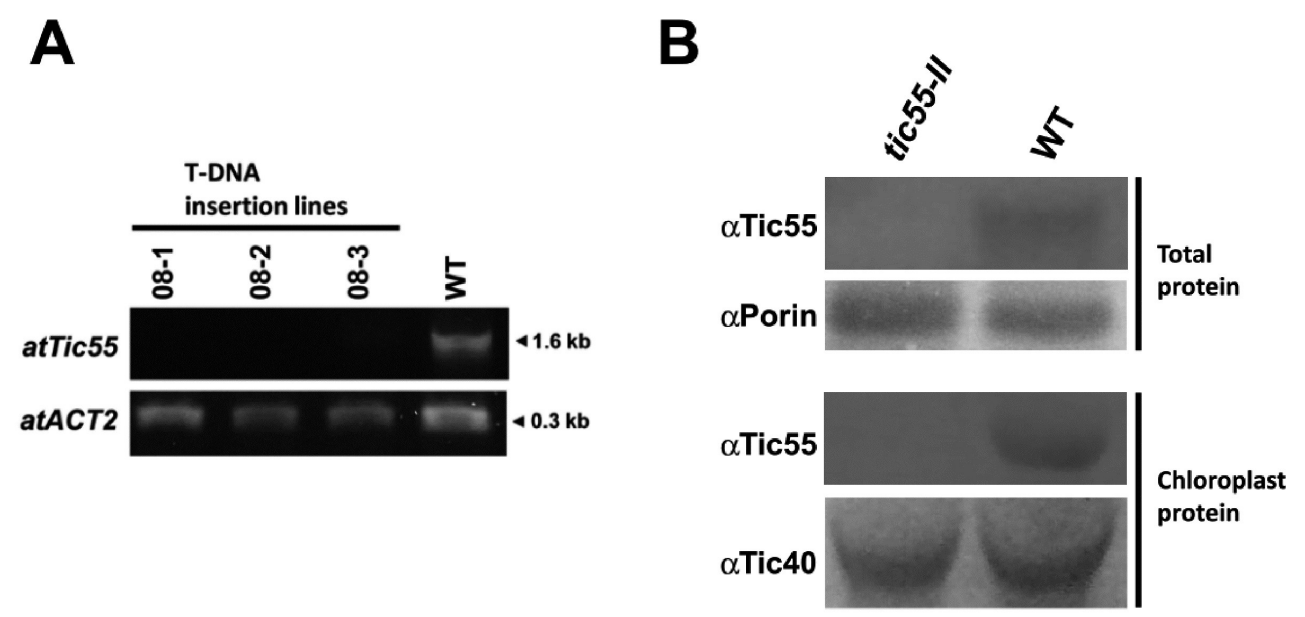

Figure 1. Molecular characterization of T-DNA insertion lines derived from SALK_086048. (A) RT-PCR analysis was performed using RT-F and RT-R primers as indicated in Table S1. Tic55 in A. thaliana is shown as atTic55. Internal control was atACT2, an actin gene in A. thaliana, used to normalize sample loading. (B) Protein gel blotting assay for both total protein and chloroplast protein was performed to detect Tic55 in the wild-type (WT) and knockout mutant (tic55-II) plant extracts by using a Tic55-specific antibody ( $\alpha$ Tic55) or the housekeeping protein porin ( $\alpha$ Porin) and Tic40 ( $\alpha$ Tic40). 
A
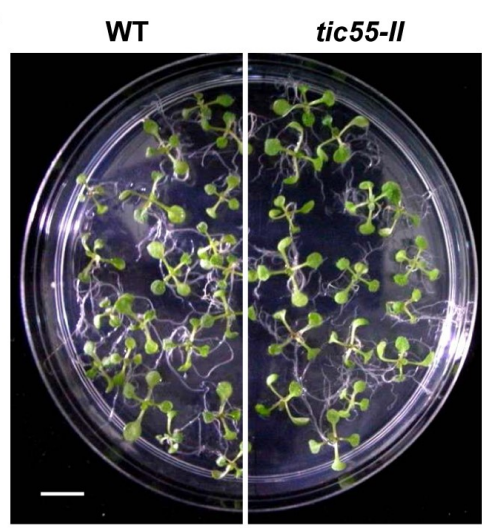

B
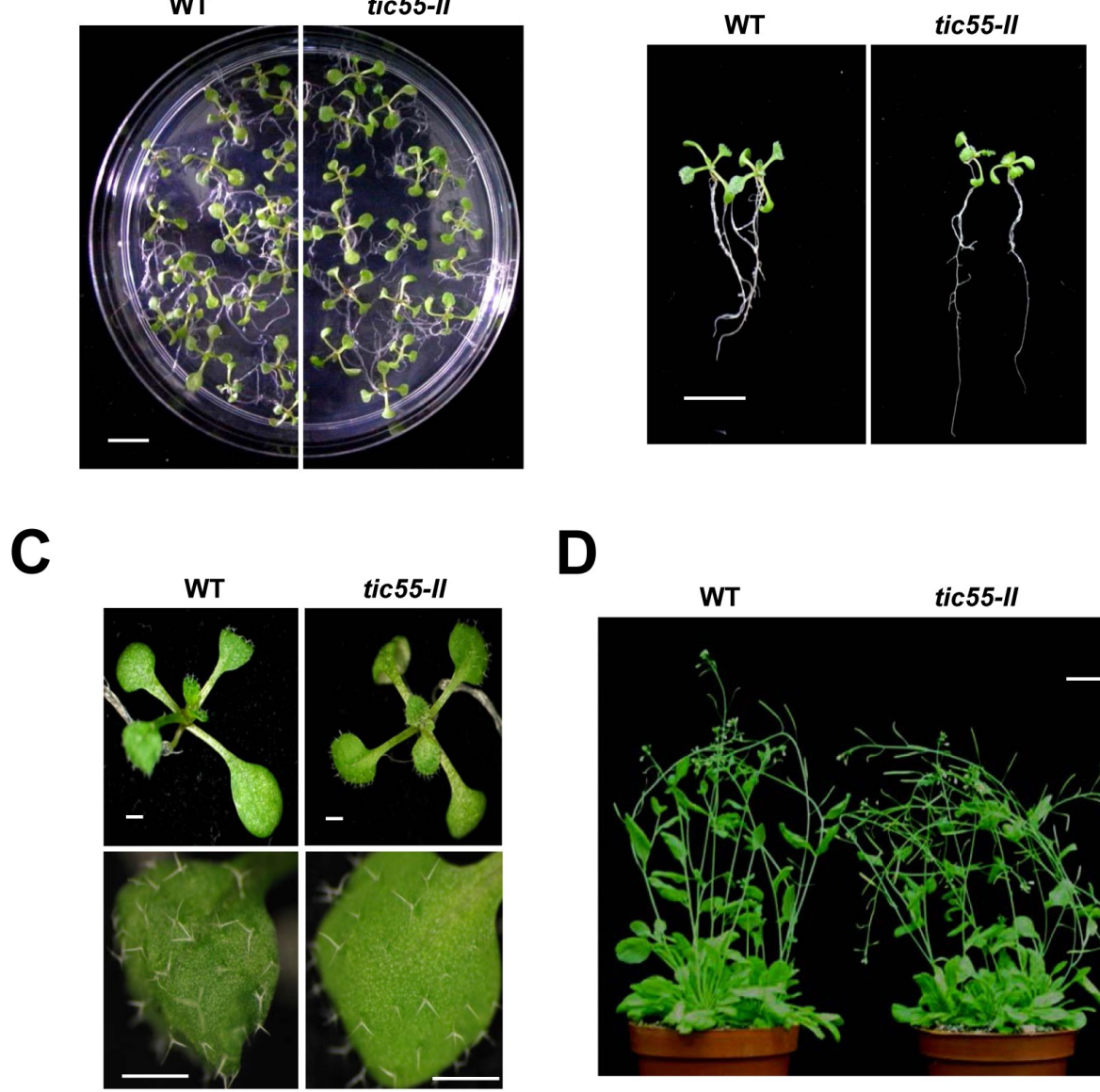

tic55-II

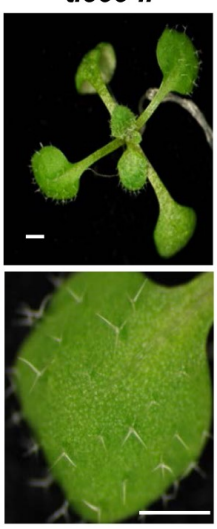

D

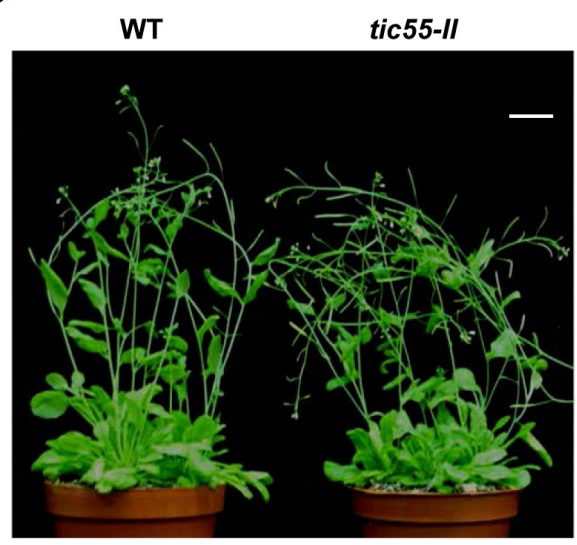

Figure 2. Phenotypes of the wild-type (WT) and tic55-II-knockout mutant lines. (A) WT and tic55-II-knockout (SALK_086048) mutant lines were grown on MS medium side by side for 10 days, and the appearance of seedlings were compared. White bar indicates $1 \mathrm{~cm}$. (B) Comparison of root systems of 10-day-old WT and tic55-II-knockout mutant seedlings, respectively. White bar represents $1 \mathrm{~cm}$. (C) Leaf tissues in (A) were photographed at closer distances for both WT and tic55-II-knockout mutant plants (upper panel). Lower panel shows the number of leaf hairs for both WT and tic55-II-knockout mutant plants. White bar (white line) indicates $1 \mathrm{~mm}$. (D) Similar plants were grown in vitro for 10 days and then transferred to soil and grown for 30 days. White bar represents $2 \mathrm{~cm}$.

\subsection{The Relationship between Tic55 and Other Translocon Proteins}

Most chloroplast proteins are nuclear-encoded preproteins that are synthesized in the cytosol, directed to the chloroplast by the transit peptide at the $\mathrm{N}$-terminus of the preprotein, and translocated into the chloroplast. After successful import, the transit peptide is cleaved off by the SPP, resulting in the mature form of the protein. Eight proteins are involved in preprotein import at the IM of the chloroplast: Tic110, Tic62, Tic55, Tic40, Tic32, Tic22, Tic21, and Tic20 [4]. Recently, Tic56, Tic100, and Tic214 were reported to be associated with Tic20 to form the 1 MDa complex at the IM, which also functions as a translocation channel for preproteins [9,12]. In addition, a defect in Tic110 resulted in the death of mutant plants, indicating that Tic110 is essential in protein import machinery [60]. However, the tic55-II-knockout mutant plants exhibited no significant phenotypic differences from the WT (Figure 2), indicating that Tic55 may not be functionally critical to the survival of $A$. thaliana in normal growth conditions.

Boij and others [21] demonstrated that only atTic55-II, but not AtPTC52 (atTic55-IV), can be considered a plausible ortholog of the pea Tic55 protein (psTic55) because the amino acid sequences 
of atTic55 and AtPTC52 are only 26\% identical, but they are 79\% identical for psTic55 and atTic55-II. To determine whether atTic55-II would affect the level of translocon proteins involved in the protein import machinery, total proteins from 14-day-old WT, tic55-II-knockout, and tic40-2 mutant lines under normal growth conditions were extracted. Between the tic55-II-knockout mutant and WT, protein quantities were similar for the outer membrane component Toc159, the inner membrane components Tic110 and Tic40, and the stromal protein Hsp93 (Figure 3A). Therefore, a defect in Tic55 does not affect the cellular levels of other translocon proteins essential to precursor protein translocation into the chloroplast stroma.
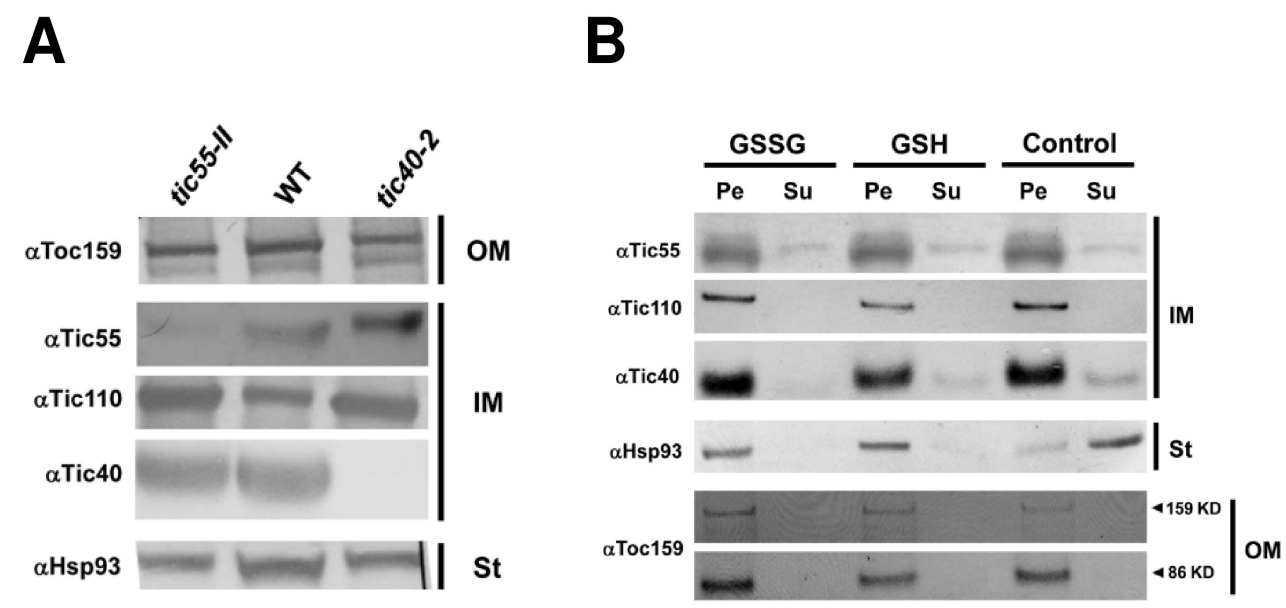

Figure 3. Relationship of Tic55 and other translocon proteins. (A) Protein gel blot analysis demonstrating the location of the inner membrane proteins Tic110 and Tic40, the outer membrane protein Toc159, and the stoma protein Hsp93 in tic55-II-knockout or tic40-2 mutants and WT plants. (B) Location of Tic55 and other translocon proteins under redox environments. Chloroplast fraction was treated with oxidized glutathione (GSSG) and reduced glutathione (GSH). Control indicates no treatment. After ultracentrifugation, lipid-soluble $(\mathrm{Pe})$ and water-soluble $(\mathrm{Su})$ protein fractions were separated and examined using protein gel blots to explore the location and complex formation of Tic55 with other translocon proteins. IM: inner membrane. St: stroma. OM: outer membrane.

Tic55 is located in the inner membrane of chloroplast in peas [19]. To determine the location of Tic55 in A. thaliana, chloroplasts were isolated through fractionation analysis and separated into four parts: the IM, OM, thylakoid membrane, and stroma. Protein gel blots indicate that Tic55 was fractionated in the IM of chloroplast in A. thaliana (Figure S1A and Figure 3A).

Furthermore, reports have demonstrated that in A. thaliana, AtTic55 (At2g24820) has a role in redox regulation and is possibly regulated by its thioredoxins $[19,61]$. Other translocon proteins alter protein-protein interactions depending on the cellular redox state. For example, Tic62 and Tic32 form distinct complexes with nearby proteins under oxidizing conditions (high $\mathrm{NADP}^{+} / \mathrm{NADPH}$ ratio) compared with those under reducing conditions (low $\mathrm{NADP}^{+} / \mathrm{NADPH}$ ratio) [62]. Similarly, to explore whether the redox environment affects the complex formation of Tic55 with other translocon proteins, we first confirmed whether Tic55 forms a complex with other translocon proteins, including Tic110, Tic40, and Hsp93, through coimmunoprecipitation (CO-IP) assays. Isolated chloroplast membrane proteins were immunoprecipitated with either specific anti-Tic55 antibody or preimmune serum (negative control), followed by protein gel blot assay with antibodies against Tic110, Tic40, or Hsp93. Tic55 appeared to form a complex with Tic110, Tic40, and Hsp93 (Figure 4). Furthermore, we used oxidized glutathione (GSSG) and reduced glutathione (GSH) to create oxidizing and reducing environmental conditions, respectively, for the isolated chloroplasts, followed by protein gel blot analysis with a specific antibody to detect particular translocon proteins. As shown in Figure 3B, Tic55 
fractionated with Tic110 and Tic40 at the IM in the presence of either GSSG or GSH, indicating the redox environments did not affect the protein-protein interactions of Tic55 and its nearby translocon proteins.
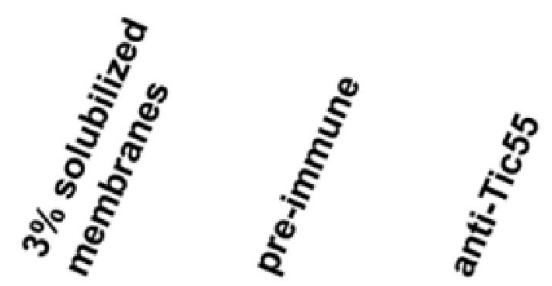

\title{
$\alpha$ Tic110
}

$\alpha \mathrm{Hsp93}$

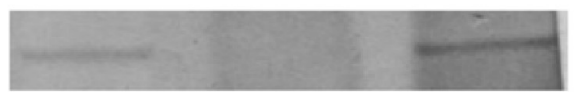

$\alpha$ Tic40

\begin{abstract}
Figure 4. Tic55 could directly interact with other Tic proteins. Coimmunoprecipitation (Co-IP) analysis was used to determine complex formation between Tic55 and other translocon proteins. Isolated chloroplasts from wild-type $A$. thaliana were treated with ice for $15 \mathrm{~min}$, followed by hypotonic treatment. Chloroplast membrane proteins were subsequently retrieved, and an immunoprecipitation (IP) assay was performed using either anti-Tic55 antibody or preimmune serum (negative control). Next, protein gel blots were conducted using specific antibodies $\alpha$ Tic110, $\alpha$ Hsp93, or $\alpha$ Tic 40 to detect whether a particular translocon protein could be coimmunoprecipitaed to indicate that the protein can form a complex with Tic55 protein.
\end{abstract}

\subsection{Possible Novel Biological Function of Tic55 in the Aging of A. thaliana}

Our data indicate that the physical appearance, other translocon proteins levels, and Tic complex formation under oxidizing or reducing environments do not differ between the tic55-II-knockout mutant and the WT. Dark-stimulated aging has a major effect on chlorophyll degradation in plants. Notably, similar to Tic55, some proteins from the LLS1-related nonheme family are involved in different stages of chlorophyll metabolism. For example, PAO and CAO are implicated in chlorophyll degradation [63]. Studies have also shown that LLS1 suppressed cell death in maize cells [64]. Therefore, Tic55 may play a role in the aging of Arabidopsis [65]. To test this hypothesis, dark-induced leaf senescence experiments (IDLs) [48] were conducted on soil-grown WT and tic55-II-knockout mutant plants. Dark treatment was applied to the expanding third and fourth rosette leaves (Figure 5A, Control Day 0) when both WT and tic55-II-knockout mutant plants were grown under long-day conditions. No apparent differences were noted between WT and tic55-II-knockout mutant plants in the control leaves (unshaded leaves) after five days of growth (Figure 5A, Control Day 5). However, IDLs of the tic55-II-knockout mutant exhibited a greener phenotype than did the WT (Figure 5A, Control Day 5 and IDL Day 5). We also measured the total chlorophyll concentrations of the WT and tic55-II-knockout mutant plants, our data showed that at Day 5, IDLs from the mutant plants retained significantly more chlorophyll than did the IDLs from the WT plants (Figure 5B). Thus, these results indicate reduced chlorophyll degradation in the dark and in the absence of Tic55, suggesting Tic55 may play a role in leaf senescence. Notably, our results corroborate the recent findings that Tic55 functions as a hydroxylase in chlorophyll breakdown during plant senescence [22]. 

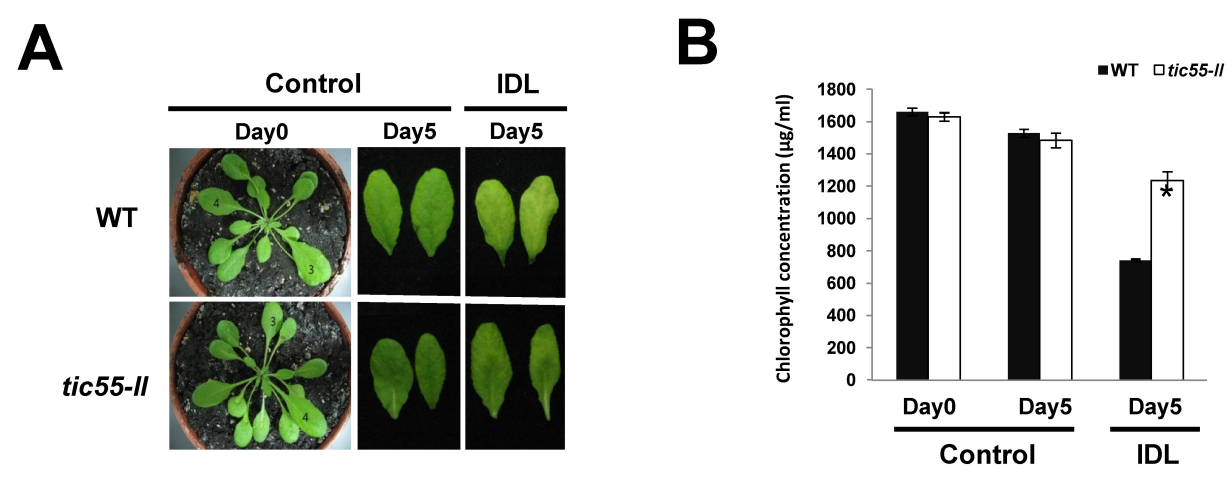

Figure 5. Dark-induced aging and the importance of Tic55 in senescence. (A) Phenotypes of wild-type (WT) and tic55-II-knockout mutant lines without treatment on both Day 0 and Day 5 (Control Day 0 and Control Day 5, respectively) compared with the IDLs of WT and tic55-II-knockout mutant lines at Day 5 after dark treatment (IDL Day 5). The third and fourth rosette leaves of Day 0 plants were individually covered with foil soon after bolting, and the plants were grown for another five days. (B) Quantitative chlorophyll analysis: The fifth and sixth leaves of 19-day-old seedlings were collected as Day 0 samples. After five days, the fifth and sixth leaves of the control seedlings (without dark treatment) were gathered as Day 5 samples. The fifth and sixth leaves of dark-treated plants were collected five days after treatment started on Day 0 (IDL Day 5). Chlorophyll was extracted and quantified $(\mu \mathrm{g} / \mathrm{mL})$ in leaves gathered from each group. Solid bars represent WT and open bars indicate tic55-II-knockout mutant lines. Three independent experiments were performed and standard deviation was measured. Asterisk $\left(^{*}\right)$ depicts $p<0.05$.

\subsection{Microarray Gene Expression Analysis in IDLs during Leaf Senescence of A. thaliana}

Dark-induced leaf senescence experiments revealed that tic55 gene knockout led to the delay of leaf aging (Figure 5) and decrease in the expression of some senescence-associated genes (SAGs) in A. thaliana. To obtain further insight into whether a defect in Tic55 affects other biological pathways during leaf aging, we performed transcriptomic analysis by using microarray technology. Both WT and tic55-II-knockout mutant plants were provided dark-induced senescence treatment (IDL treatment) for three days, following which their leaves were collected. After a microarray assay, as indicated in the Materials and Methods section, differential gene expression associated with biological processes, cellular components, or molecular functions was analyzed (Figure 6). A $\log _{2}$ fold cutoff $(p<0.05)$ was applied to the data, resulting in a total of 923 highly significant differentially expressed genes (Figure 6). On comparing the IDLs of the tic55-II-knockout mutant and the WT, we identified 252 induced and 671 repressed transcripts after three days of growth. The fold change expression data was then assigned to a functional category according to the GO classification system for plants developed at TAIR (http:/ / www.arabidopsis.org/help/helppages/go_slim_help.jsp) [49,50]. The functions of the identified genes cover various biological processes, cellular components, and molecular functions. In total, 830 transcripts were grouped into three main GO categories and 111 subcategories (functional groups) (Table S2). 


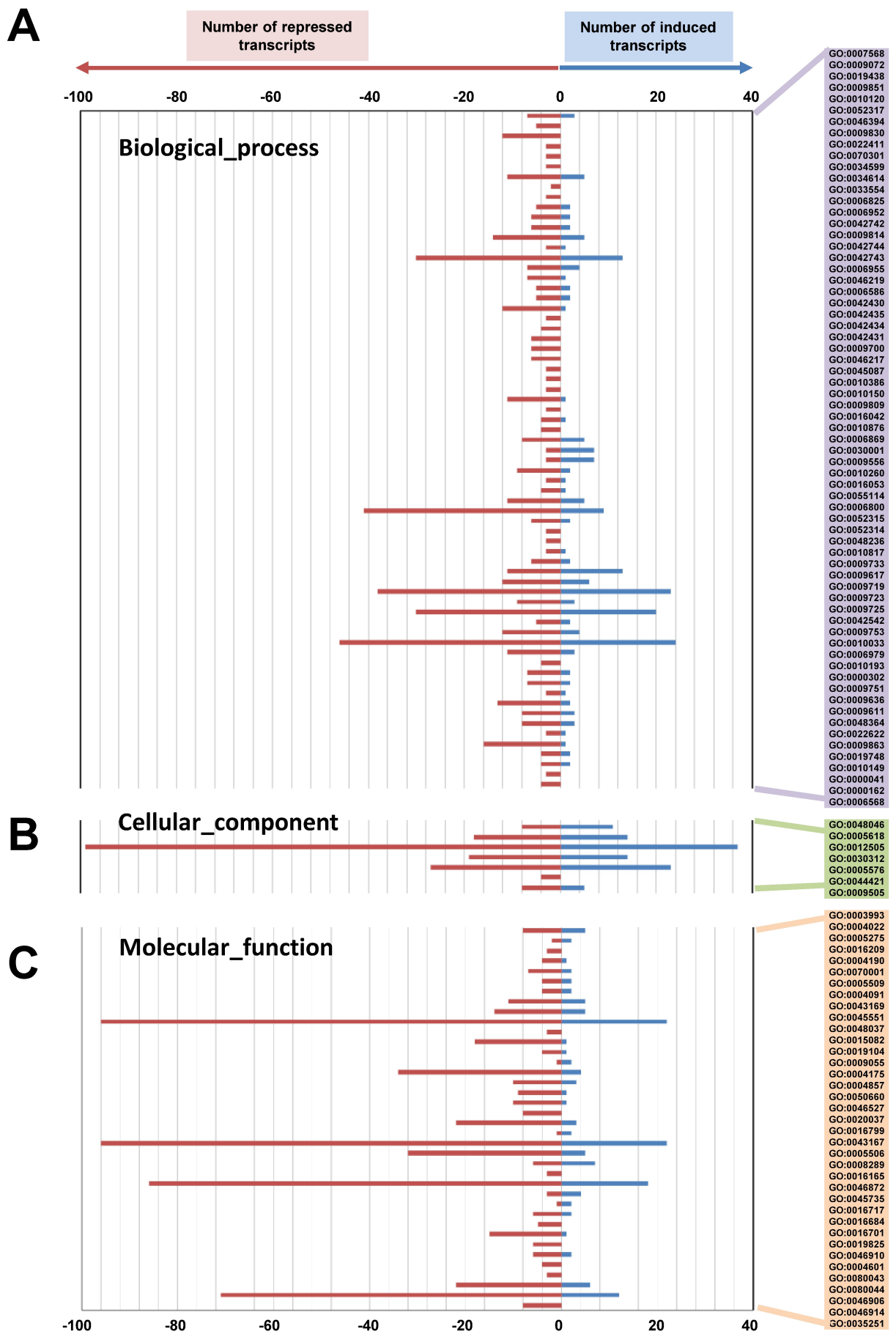

Figure 6. Regulated genes ( $\log _{2}$-fold change) assigned to functional protein categories based on the gene ontology (GO) classification scheme. These genes are involved in the biological processes (A), cellular components (B), or molecular functions (C). Positive and negative values on the scale indicate the numbers of significantly up- and downregulated genes, respectively.

\subsection{Functional Categorization of $\log _{2}$-Fold Induced and Repressed Genes in the IDLs Based on} Microarray Analysis

The patterns of transcript fold changes for upregulated and downregulated genes were further examined and classified according to their GO functional categories derived from our microarray analysis (Table S2). The trend for each subcategory presented a significant increase $(p<0.05)$ in the total 
number of differentially regulated (repressed and induced) genes from the IDLs of tic55-II-knockout mutants after dark-induced leaf senescence. Of these differentially expressed transcripts, the repressed genes increased the most in each subcategory (Table S2). Thus, our microarray data indicated that dark-induced aging in the tic55-II-knockout mutant, which has the defective Tic55, would subsequently affect the downstream genes expression involved in regulating the developmental stages in $A$. thaliana.

\subsection{Confirmation of Microarray Results by Real-Time $q R T-P C R$}

The results of our dark-induced leaf senescence experiments in tic55-II-knockout mutant showed increased chlorophyll concentration compared to WT (Figure 5B), and differential gene expression involved in the regulation of leaf aging in our microarray data in the absence of Tic55 (Figure 6, Table S2). In addition, a developmental tissue-specific expression profile for atTic55 revealed that the highest expression levels are in the photosynthetic tissues, according to publicly available Affymetrix GeneChip microarray data, accessed using the Genevestigator analysis tool (www.genevestigator.ethz.ch/). Notably, Tic55-II expression is augmented not only in the cotyledons, sepals, and cauline leaves, but also in the senescent leaves in terms of tissue-specific expression, suggesting that Tic55-II gene expression increases in response to leaf aging [21]. To further explore whether Tic55 is crucial in regulating senescence-associated genes (SAGs) expression, we conducted microarray analysis using dark-induced aging leaves from the tic55-II-knockout mutant and identified differentially expressed genes in this mutant when compared to the WT (Table S2). Our microarray data revealed that several genes are classified into the biological processes categories divided into the subcategories of "aging" (three upregulated and seven downregulated), "senescence" (four downregulated), and "leaf senescence" (four downregulated) (Table S2). We thus selected seven genes for further analysis on the basis of their possible involvement in leaf senescence in A. thaliana [51-58]: ASP3, APG7, DIN2, DIN11, $S A G 12, S A G 13$, and YLS9. According to microarray analysis, these genes are downregulated in the tic55-II-knockout mutant (Table 1), indicating the aging-related gene expression is repressed under dark-induced senescence in the absence of functional Tic55, thus delaying leaf senescence.

Table 1. List of significantly upregulated or downregulated genes in aging, senescence, and leaf senescence subcategories from biological processes categories according to the gene ontology classification scheme from microarray analysis. Data provided represent fold expression $\log _{2}$ (tic55-II-knockout/wild type).

\begin{tabular}{ccccc}
\hline Locus ID & GO Term & Annotation & Up or Down & $\begin{array}{c}\text { Fold Change } \\
\text { (tic55-II/WT) }\end{array}$ \\
\hline NM_180632 & $\begin{array}{c}\text { GO:0007568 aging } \\
\text { GO:0010149 senescence } \\
\text { GO:0010150 leaf senescence }\end{array}$ & $\begin{array}{c}\text { Arabidopsis thaliana } \text { epithiospecifier } \\
\text { protein mRNA (ESP) }\end{array}$ & Up & 2.452 \\
\hline NM_124040 & GO:0007568 aging & $\begin{array}{c}\text { Arabidopsis thaliana tetraspanin } \\
\text { family protein mRNA (TRN2) }\end{array}$ & Up & 2.017 \\
\hline NM_001036860 & $\begin{array}{c}\text { GO:0007568 aging } \\
\text { GO:0010149 senescence }\end{array}$ & $\begin{array}{c}\text { Arabidopsis thaliana vegetative } \\
\text { storage protein 2 mRNA (VSP2) }\end{array}$ & Up & 2.009 \\
\hline NM_121190 & $\begin{array}{c}\text { GO:0007568 aging } \\
\text { GO:0010149 senescence } \\
\text { GO:0010150 leaf senescence }\end{array}$ & $\begin{array}{c}\text { Arabidopsis thaliana aspartate 3 } \\
\text { aminotransferase mRNA (ASP3) }\end{array}$ & Down \\
\hline GM_129157 & $\begin{array}{c}\text { GO:0010149 senescence } \\
\text { GO:0010150 leaf senescence }\end{array}$ & $\begin{array}{c}\text { Arabidopsis thaliana late } \\
\text { embryogenesis abundant } \\
\text { hydroxyproline-rich } \\
\text { glycoprotein mRNA (YLS9) }\end{array}$ & Down & -2.107 \\
\hline \multirow{2}{*}{ NM_123958 } & $\begin{array}{c}\text { GO:0007568 aging } \\
\text { GO:0010149 senescence }\end{array}$ & $\begin{array}{c}\text { Arabidopsis thaliana } \text { ubiquitin-like } \\
\text { modifier-activating enzyme } \\
\text { atg7 mRNA (APG7) }\end{array}$ & Down & -2.533 \\
\hline
\end{tabular}


Table 1. Cont.

\begin{tabular}{|c|c|c|c|c|}
\hline Locus ID & GO Term & Annotation & Up or Down & $\begin{array}{l}\text { Fold Change } \\
\text { (tic55-II/WT) }\end{array}$ \\
\hline NM_201829 & GO:0007568 aging & $\begin{array}{c}\text { Arabidopsis thaliana } \\
\text { senescence-associated protein } \\
13 \text { mRNA (SAG13) }\end{array}$ & Down & -3.353 \\
\hline NM_115877 & GO:0007568 aging & $\begin{array}{l}\text { Arabidopsis thaliana beta-glucosidase } \\
30 \text { mRNA (DIN2) }\end{array}$ & Down & -3.735 \\
\hline NM_115877 & GO:0007568 aging & $\begin{array}{c}\text { Arabidopsis thaliana } \\
\text { 2-oxoacid-dependent } \\
\text { dioxygenase-like protein } \\
\text { DIN11 mRNA (DIN11) }\end{array}$ & Down & -3.735 \\
\hline NM_123957 & $\begin{array}{c}\text { GO:0007568 aging } \\
\text { GO:0010149 senescence } \\
\text { GO:0010150 leaf senescence }\end{array}$ & $\begin{array}{c}\text { Arabidopsis thaliana cysteine } \\
\text { protease mRNA (SAG12) }\end{array}$ & Down & -7.388 \\
\hline
\end{tabular}

To confirm the differential gene expression profiles obtained from microarray assay, we validated expression values through relative real-time qRT-PCR. Both IDLs from Columbia WT and tic55-II-knockout mutants were collected, followed by real-time qRT-PCR. All seven genes showed the same expression patterns as they did in the microarray analysis, demonstrating the reliability of the microarray results (Figure 7). However, the fold changes determined through microarray analysis and real-time qRT-PCR were slightly different. This may have been due to technical differences in the analysis and normalization methods. Nevertheless, our results demonstrated that the expression of these aging-related genes decreased without functional Tic55 in the tic55-II-knockout mutant under dark treatment, thus delaying leaf senescence and causing greener phenotypes in their leaves than in those of the WT (Figure 5A). Therefore, the biological function of Tic55 is involved in plant senescence. Our data corroborate the recent reports of Hauenstein et al. [22], who demonstrated that Tic55 is involved in the hydroxylation of phyllobilins, the products of chlorophyll breakdown during senescence. These authors mainly focused on the elucidation of biological activity of Tic55, whereas our study revealed not only the direct effect of Tic55 on chlorophyll catabolism but also its indirect role in the downstream senescence associated genes (SAGs) expression through microarray and qRT-PCR analyses. Consequently, we propose that Tic55 expression is increased when a leaf enters the normal aging stage, subsequently affecting the downstream senescence-associated gene expression, leading to leaf senescence.

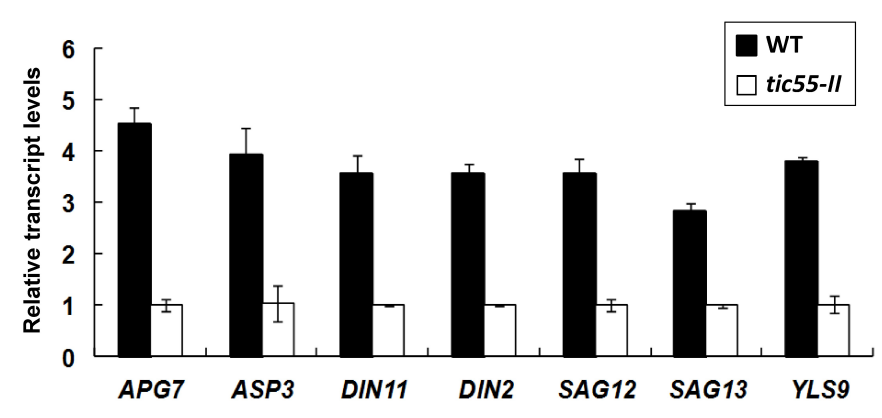

Figure 7. Validation of microarray expression data by relative real-time quantitative RT-PCR. Validated leaf senescence-related genes, namely ASP3, APG7, DIN2, DIN11, SAG12, SAG13, and YLS9, showed downregulation in the tic55-II-knockout mutant after dark-induced leaf senescence compared with the wild-type (WT) in microarray analysis. Relative transcript levels of these genes were determined using three replicates, and signal intensities for each transcript were normalized with tubulin (internal control). Error bars represent standard deviation. Primers used in PCR reactions are listed in Table S1. Each experiment was repeated three times with similar results. Black and white boxes indicate the Columbia WT and tic55-II-knockout mutant, respectively. 


\subsection{Sequence Alignment and Phylogenetic Analysis of ANAC TFs}

Multiple layers of regulation are involved in the control of leaf senescence. An overview of these multiple controlling layers has been shown recently, including chromatin-mediated, transcriptional, post-transcriptional, translational, and post-translational modes of regulation [44]. From the onset through the completion of leaf senescence, it is a highly coordinated process and involves an extensive rearrangement of gene expression $[44,66]$. The regulation of plant senescence has been related to thousands of senescence-associated genes (SAGs) $[52,53,57]$, including $S A G 12$ and SAG13, which we have found downregulated from our microarray data and confirmed by qRT-PCR analysis in the dark-induced tic55-II-knockout mutant, which led to delayed leaf senescence. Earlier studies have shown that Arabidopsis SAG12 is an important molecular marker specific for leaf senescence, while not detected in the hypersensitive response (HR) linked programmed cell death (PCD) in tobacco. Similarly, HSR2037 is upregulated during HR, but not in leaf senescence [67]. This observation indicates that signaling pathway linked leaf senescence-associated cell death is distinct from those of other HR PCDs. Thus, our results are in accord with this notion in which expression of SAGs is highly associated with the process of leaf senescence. Although leaf senescence is considered a complex process, upstream NAC transcription factors (TFs) appear to play essential roles in senescence and over 100 NAC genes have been found in Arabidopsis by transcriptome analyses, thereby implicating NAC genes as important regulators of the senescence process [33,59]. From our microarray data of dark-induced senescence in tic55-II-knockout mutant, we identified four downregulated genes encoding NAC domain-containing proteins, including ANAC003, ANAC010, ANAC042, and ANAC075, whereas no upregulated NAC genes were found. The common subdomains (A-E) of protein sequences were determined by MEME/MAST analysis [68] and MEGA 6.0 [69] was used to construct the phylogenetic tree by the neighbor-joining method with 1000 bootstrap replicates [70,71]. As shown in Figure 8A, alignment of four downregulated Arabidopsis NAC-containing proteins, ANAC003, ANAC010, ANAC042, and ANAC075, in response to dark stress in tic55-II-knockout mutant appeared the typical domain structure (subdomains A-E) at N-terminal end as other NAC-containing proteins, such as ANAC019 whose crystal structure was identified [41]. Our results therefore are in agreement with those of earlier studies [24,42] in that the N-terminal portion with the NAC domain of our four downregulated NAC proteins is highly conserved, whereas the C-terminal region is divergent (Figure 8A). According to the study of Podzimska-Sroka and others [72], ANAC003 and ANAC042 are senescence-associated proteins in Arabidopsis. Their notion further supports our microarray data in that downregulated ANAC003 and ANAC042 found in tic55-II-knockout mutant are very likely to be associated with leaf senescence. In addition, recent studies have revealed that plant signaling pathways are composed of complicated network with cross-talks [73]. In fact, several Arabidopsis NAC genes were identified as convergence points between different pathways, such as ANAC019, ANAC055 [35,74] and ANAC072 (RD26) [34], indicating the important role of NAC genes involved in plants in response to abiotic and biotic stresses. Furthermore, these three genes were found to be age-related NAC genes [32]. To analyze the relative relationship among the identified NAC proteins, phylogenetic tree of these NAC TFs and other NAC proteins was constructed as illustrated in Figure 8B. 


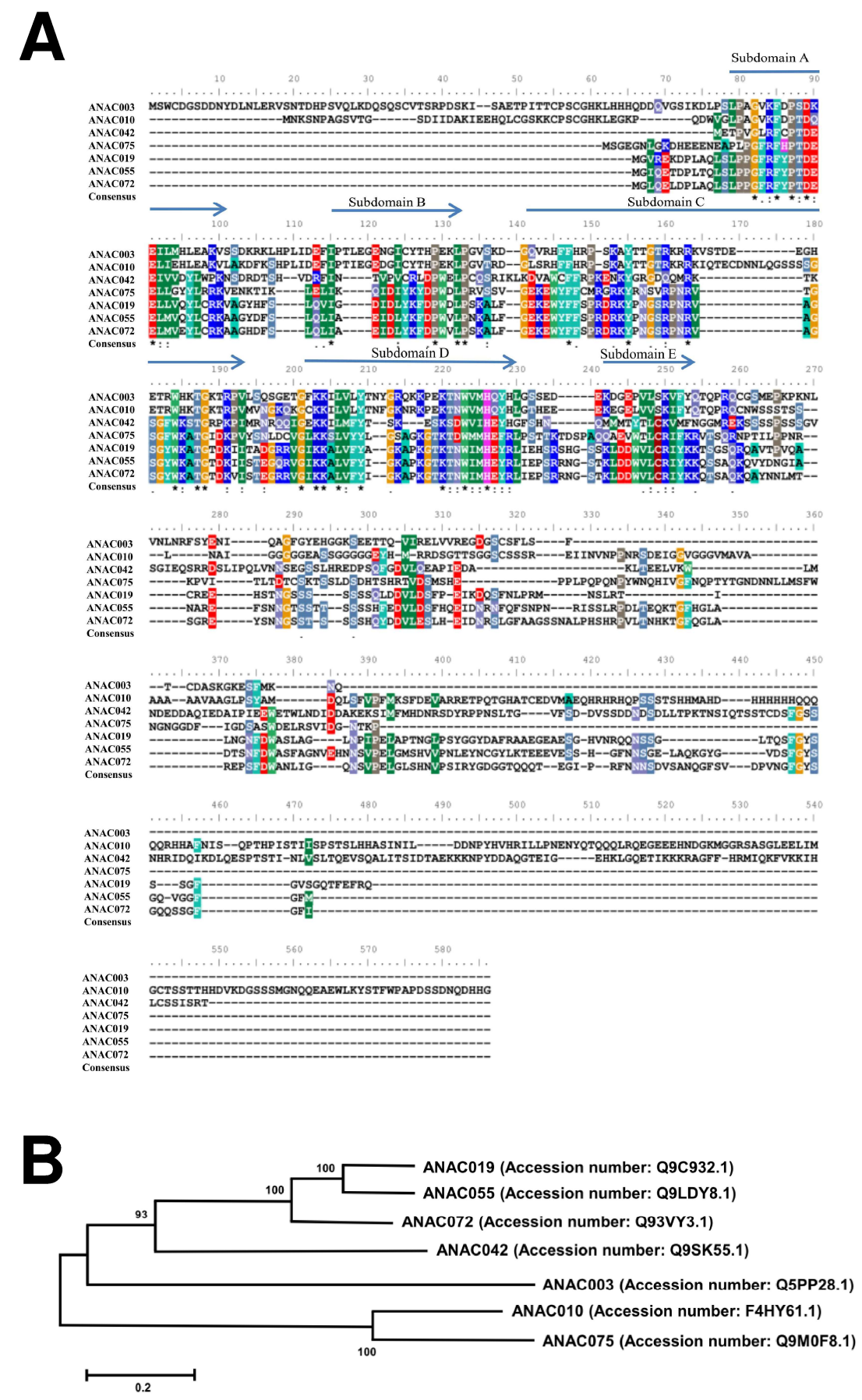

Figure 8. ANAC domain structure of seven Arabidopsis NAC transcription factors (TFs). (A) Architecture of NAC containing domains of seven Arabidopsis NAC TFs. * indicates the identical amino acids aligned within the different ANAC proteins. (B) phylogenetic relationships of four downregulated ANAC proteins, including ANAC003, ANAC010, ANAC042, and ANAC075 with other ANAC proteins that have been previously published involved in plant senescence.

\subsection{MYB-NAC Linked Regulatory Pathway and Leaf Senescence}

To validate whether NAC transcription factor genes, including ANAC003, ANAC010, ANAC042, and $A N A C 075$ are repressed in the tic55-II-knockout mutant after dark-induced leaf senescence, relative real-time quantitative RT-PCR assays were conducted. As shown in Figure 9A, these four NAC genes were indeed downregulated in the tic55-II-knockout mutant following dark-induced leaf aging when 
compared with the wild type (WT). Furthermore, members of a MYB TF family group, including MYB2, MYB21, MYB108, and MYB112 have been found to interact with the promoter of a NAC gene, $A N A C 055$, in a sequence-specific manner [32]. In agreement with this notion is the presence of a MYB binding motif $[32,75]$. Thus, members of this MYB subgroup are involved in regulating the same stress responses as the NAC TFs. MYB108 revealed to be implicated in response to ABA, JA, and ethylene and also involved in regulating the response to pathogen infection [76,77]. In addition, Hickman and coworkers [32] have shown a gene regulatory network in which the expression of ANAC019, ANAC055, and $A N A C 072$ was regulated directly by the upstream MYB108, which was determined by using the yeast one-hybrid assays. Since we identified downregulated MYB108 as well as four ANAC genes, including ANAC003, ANAC010, ANAC042, and ANAC075 from Microarray analysis of dark stressed tic55-II-knockout mutant, similar yeast one-hybrid experiments were performed. Our data showed that indeed MYB108 interacts with the promoter of $A N A C 003$ gene, indicating dark-induced leaf senescence in tic55-II-knockout mutant is associated with the MYB108 linked NAC regulatory pathway (Figure 9B). In addition, PCR reactions confirmed that both MYB108 and NAC constructs were introduced into yeast cells and thus the results of yeast one-hybrid assays were reliable. The possible MYB TF binding sites for all four $A N A C$ genes are exhibited in Table 2. Furthermore, our results revealed that MYB108 interacts with the promoter of ANAC003, while not with those of ANAC010, ANAC042 or ANAC075, suggesting different control mechanisms involved in regulating ANAC010, ANAC042 and ANAC075 expression. Earlier studies have shown WRKY, bZIPs, HB TFs, or other NAC proteins could be other possible upstream regulatory factors [32]. Taken together, our results suggest that MYB-NAC TFs regulatory singling is involved in the dark induced Tic55-associated plant senescence by a complex transcriptional network.
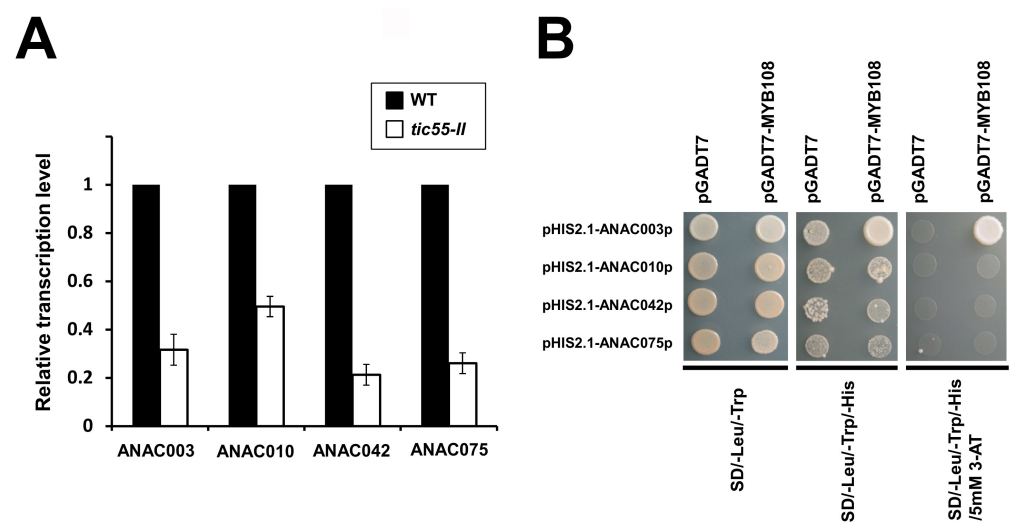

Figure 9. Downregulated expression of four $A N A C$ genes accessed by relative real-time quantitative RT-PCR and MYB-NAC relationship determined by yeast one-hybrid assay. (A) Validated leaf NAC transcription factor genes, including ANAC003, ANAC010, ANAC042, and ANAC075 showed downregulation in the tic55-II-knockout mutant after dark-induced leaf senescence compared with the wild-type (WT) in microarray analysis. Relative transcript levels of these genes were determined using three replicates, and signal intensities for each transcript were normalized with tubulin (internal control). Error bars represent standard deviation. Primers used in PCR reactions are listed in Table S1. Black and white boxes indicate the Columbia WT and tic55-II-knockout mutant, respectively. (B) Interaction between MYB108 TF and promoters of different $A N A C s$ was analyzed. Promoter region of different ANAC genes was linked to the HIS3 reporter gene, resulting in different constructs: pHIS2.1-ANAC003p, pHIS2.1-ANAC010p, pHIS2.1-ANAC042p and pHIS2.1-ANAC075p. Each of these constructs was transformed into yeast cells either with plasmid carrying an Activation Domain (AD)-MYB108 TF fusion (pGADT7-MYB108) or pGADT7 plasmid as a negative control. Binding of MYB108 to the cis-elements of $A N A C 003, A N A 010, A N A C 042$, or $A N A C 075$ promoter region, resulting in the expression of reporter gene, showed the growth of yeast cells in SD/-Leu/-Trp/-His medium in the presence of 3-amino-1,2,4-triazol (3-AT). 
Table 2. Possible MYB binding sites predicted by PlantPAN 2.0 analyses [78].

\begin{tabular}{cc}
\hline NAC Genes & MYB Binding Sequences (Nucleotides No.) ${ }^{\mathbf{1}}$ \\
\hline \multirow{2}{*}{ ANAC003 } & $\begin{array}{c}\text { AGAATATAGT }(-222 \sim-231) ; \text { ATCGTATCTATGT }(-329 \sim-341) ; \\
\text { AGATAACGGA }(-356 \sim-365) ; \text { AAAGATATGTC }(-537 \sim-547) ; \\
\text { TTGATATTT (-614 -622); GGAATATTTT (-658 -667) }\end{array}$ \\
\hline \multirow{2}{*}{ ANAC010 } & TTGGTAGGTC (-33 -42); AAAATATTAT (-191 -200); TATAATCTGTT (-641 -651); \\
& TGAGATCTCT (-786 -795); GTGAAGATATGGT (-850 -862) \\
\hline \multirow{2}{*}{ ANAC042 } & AGTTATCCTTT (-133 -143); TGTGAATCTTA (-152 -162); \\
& GATAATCTGA (-302 -311); TCAGATTCTCT (-643 -653); TAAGATCTTG (-845 -854) \\
\hline \multirow{2}{*}{ ANAC075 } & AAGATATTCG (-9 -18); TTCATATCTTCAC (-132 -144); \\
& CGGTTAGGT (-218 -0226); TAAGATCTTA (-310 -319); \\
& TAAATATTTT (-725 -734); TTCATATCTC (-879 -888); \\
\hline${ }^{1}$ Nucleotide sequence numbers correspond to the sequences upstream of the transcriptional start site of their \\
respective NAC genes.
\end{tabular}

\section{Materials and Methods}

\subsection{Plant Materials and Growth Conditions}

All A. thaliana plants used in this study were of the Columbia ecotype. tic40-2 mutant plants were isolated by screening T2 seeds from a T-DNA insertion population for pale-green phenotypes (mutant line 2490) and the T-DNA insertion position was identified by plasmid rescue [79]. A. thaliana plants were grown as described previously [80]. For in vitro growth, seeds were surface sterilized, sown on $1 / 2 \times$ MS agar containing $2 \%(w / v)$ sucrose in petri dishes, and kept in a growth chamber $\left(22{ }^{\circ} \mathrm{C}, 16-\mathrm{h}\right.$ light/8-h dark). To select for the T-DNA insertion mutants, kanamycin monosulfate was added to the MS medium at a final concentration of $50 \mu \mathrm{g} / \mathrm{mL}$. Seedlings of $A$. thaliana plants were grown under a long-day cycle $\left(22^{\circ} \mathrm{C}\right.$, 16 -h light/ 8 -h dark).

\subsection{Preparation of Chloroplasts and Chloroplast Subfractions}

Intact chloroplasts were isolated from 20-day-old A. thaliana plants, as described previously [81,82]. Outer membrane (OM), inner membrane (IM), thylakoid, and stromal fractions were recovered and isolated from the supernatant through sucrose density centrifugation [83].

\subsection{Protein Gel Blot Analysis}

Proteins were separated through SDS-PAGE by using SDS gels (NuPAGE 4-12\% Bis-Tris Gel; Invitrogen, Carlsbad, CA, USA) and electroblotted on to PVDF membrane (Immobulilin P; Millipore, Bedford, MA, USA), according to the standard procedures. The membranes were immunodetected using the method of Harlow and Lane [84], with an alkaline phosphatase-linked second antibody and bromochloroindoyl phosphate (BCIP)/nitro blue tetrazolium (NBT) development.

\subsection{Coimmunoprecipitation (Co-IP) Analysis}

Intact chloroplasts were isolated from 20-day-old A. thaliana plants, as has been described in previous research [81,82]. Briefly, 20-day-old $A$. thaliana plants were ground in $1 \times$ grinding buffer (GB; 330 mM D-sorbitol, $50 \mathrm{mM}$ HEPES-KOH, pH 8.0, 2 mM EDTA, 0.5\% BSA) and filtered through two layers of Miracloth (Calbiochem, Inc., La Jolla, CA, USA). After centrifugation, the pellet was dissolved in $1 \times$ GB buffer. The chloroplast was then isolated and resuspended in $1 \times$ import buffer (600 mM D-sorbitol, $100 \mathrm{mM}$ HEPES-KOH, $\mathrm{pH} 8.0$ ) to a final concentration of $1 \mathrm{mg} / \mathrm{mL}$ after Percoll (Amersham Biosciences, UPpsala, Sweden) gradient centrifugation. Diluted chloroplast $(0.5 \mathrm{mg} / \mathrm{mL}$ ) was then treated with $0.5 \mathrm{mM}$ dithiobis succinimidylpropionate (DSP) and $50 \mathrm{mM}$ glycine, followed by $2 \times$ hypotonic buffer $(25 \mathrm{mM}$ HEPES-KOH, $\mathrm{pH} 8.0,4 \mathrm{mM} \mathrm{MgCl} 2)$. After ultracentrifugation 
at 45,000 rpm (Beckman TL-100), the pellet was dissolved in $1 \times$ solubilization buffer $(25 \mathrm{mM}$ HEPES-KOH, pH 8.0, $50 \mathrm{mM} \mathrm{KCl}, 4 \% \mathrm{Tx}-100,20 \%$ glycerol, proteinase inhibitor) and incubated on ice for $10 \mathrm{~min}$. Subsequently, $50 \mu \mathrm{L}$ of supernatant was collected, mixed with $2 \times$ sample buffer (900 mM Tris-HCl, pH 8.45, 24\% glycerol, 8\% SDS, 0.0076\% Coomassie Blue G, 0.01\% Phenol Red, $0.001 \mathrm{mM}$ EDTA, $0.1 \mathrm{mM} \mathrm{DTT}$ ), and stored at $-20{ }^{\circ} \mathrm{C}$ for further study after centrifugation. The leftover supernatant was diluted with HKG buffer (25 mM HEPES-KOH, pH 8.0, $50 \mathrm{mM} \mathrm{KCl}, 10 \%$ glycerol) and divided into two tubes. Anti-Tic55 antibody and preimmune antibody were added into separate tubes; protein A was then added into each tube following $12 \mathrm{~h}$ incubation at $4{ }^{\circ} \mathrm{C}$. After $4 \mathrm{~h}$, the pellet was washed four times with equal volume of $2 \times$ solubilization buffer and $2 \times$ HKG buffer after centrifugation. Finally, the pellet was resuspended in $30 \mu \mathrm{L}$ of $2 \times$ sample buffer and protein gel blot was performed with specific antibodies.

\subsection{Dark Treatment and Chlorophyll Concentration Analysis}

Dark-induced aging: Following Wada and others [85], the third to sixth leaves of 19-day-old WT (Columbia ecotype) and mutant (tic55-II-knockout) A. thaliana plants were either covered with aluminum foil to prevent exposure to sunlight or left untreated and collected directly as untreated controls (Day 0). On Day 5, the IDLs were uncovered and both they and the untreated (control) leaves were photographed for both WT and tic55-II-knockout plants

Chlorophyll concentration analysis: Quantitative analysis of chlorophyll a/b concentration was performed according to the method described by Porra [86]. Briefly, we collected the fifth and sixth leaves from normal and dark-treated 19-day-old seedlings; these were weighed, frozen in liquid nitrogen, and finally stored at $-80{ }^{\circ} \mathrm{C}$. The frozen leaves were then broken in $80 \%$ acetone and centrifuged. Chlorophyll was extracted and collected from the supernatant by repeating the preceding steps until the centrifuged pellets were almost completely white. The absorbance of the collected chlorophyll at 663 and $647 \mathrm{~nm}$ (A663 and A647, respectively) was determined; chlorophyll concentrations were then calculated as follows [87]:

$$
\begin{gathered}
\text { Chlorophyll a }(\mu \mathrm{g} / \mathrm{mL})=(12.25 \times \mathrm{A} 663)-(2.55 \times \mathrm{A} 647) \\
\text { Chlorophyll b }(\mu \mathrm{g} / \mathrm{mL})=(20.31 \times \mathrm{A} 647)-(4.91 \times \mathrm{A} 663) \\
\text { Total chlorophyll }(\mu \mathrm{g} / \mathrm{mL})=(18.71 \times \mathrm{A} 647)+(7.15 \times \mathrm{A} 663) .
\end{gathered}
$$

Finally, the chlorophyll concentrations were divided by the weight of the leaf tissues and multiplied by the total collected volume.

\subsection{Hybridization of A. thaliana Microarrays and Data Analysis}

Total RNA $(0.2 \mu \mathrm{g})$, isolated from each sample by using TRIzol (Invitrogen) according to the manufacturer's instructions, was amplified by using Low Input Quick-Amp Labeling Kit (Agilent Technologies, Santa Clara, CA, USA) and labeled with Cy3 (CyDye, Agilent Technologies) during the in vitro transcription process. Cy3-labeled cRNA $(1.65 \mu \mathrm{g})$ was fragmented to an average size of approximately 50-100 nucleotides through incubation with fragmentation buffer at $60^{\circ} \mathrm{C}$ for $30 \mathrm{~min}$. Correspondingly fragmented and labeled cRNA was then pooled and hybridized using a Agilent Arabidopsis V4 Oligo $4 \times 44 \mathrm{~K}$ Microarray (Agilent Technologies) at $65^{\circ} \mathrm{C}$ for $17 \mathrm{~h}$. After being washed and dried through nitrogen gun blowing, the hybridized microarrays were scanned on an Agilent microarray scanner (Agilent Technologies) at $535 \mathrm{~nm}$ for Cy3. The scanned images were analyzed using Feature extraction 10.5.1.1 software (Agilent Technologies); image analysis and normalization software were used to quantify signal and background intensity for each feature, respectively. The data points with nonzero flag values or $<2.6$ signal-to-noise ratios were masked. The remaining data were $\log _{2}$-transformed and averaged for each gene. For selecting genes significantly expressed in the tic55-II-knockout mutant after dark treatment compared with the WT, a 2-fold change and 
$p$ ValueLogRatio of $<0.05$ were used as thresholds. The GO Slim Classification for Plants, developed at TAIR (http:/ / www.arabidopsis.org/help/helppages/go_slim_help.jsp), was used to characterize the functionally upregulated and downregulated genes. The GO identifier of the optimal hit (with a cutoff of $E$-value $<10^{-5}$ ) was attributed to the sequence. This step allowed putative functions to be assigned on the basis of the classification proposed by the GO.

\subsection{Relative Real-Time $q R T-P C R$ and Microarray Validation}

Real-time qRT-PCR was used to validate selected data from the microarray experiments and examine the expression of a subset of genes over time. The leaf senescence-related genes, namely ASP3, APG7, DIN2, DIN11, SAG12, SAG13 and YLS9, and primers used for the qRT-PCR assays are listed in Table S1. The cDNA was synthesized from $1 \mu \mathrm{g}$ of total RNA in a volume of $20 \mu \mathrm{L}$ using the GoScript ${ }^{\mathrm{TM}}$ Reverse Transcription System (Promega, Madison, WI, USA), according to the manufacturer's instructions. The cDNA products were diluted and used for real-time qPCR analysis, which was performed using a PTC-200 thermal cycler and real-time fluorescence monitoring by a Chromo 4 optical detector (MJ Research/Bio-Rad, Hercules, CA, USA) with the SYBR Green Master Mix (Toyobo) for transcript measurements. Amplification conditions were as follows: one cycle at $95^{\circ} \mathrm{C}$ for $1 \mathrm{~min}$, followed by 35 cycles of $95^{\circ} \mathrm{C}$ for $15 \mathrm{~s}$ and then $60{ }^{\circ} \mathrm{C}$ for $60 \mathrm{~s}$, with plate reading conducted after each cycle. The Arabidopsis tubulin gene (TUB2) was used as the endogenous control. After the completion of PCR amplification, all data from three replicated qRT-PCR samples were analyzed using Bio-Rad CFX Manager ${ }^{\mathrm{TM}}$ (version 1.5.534.0511, Hercules, CA, USA) to the $2^{-\Delta \Delta C t}$ method [87].

\subsection{Transactivation Assays in Yeast Cells}

A yeast one-hybrid assay (Clontech) was performed to determine whether MYB108 can activate the promoter regions of downstream target transcription factors, including ANAC003, ANAC010, ANAC042 and ANAC075, which were chosen based on the results of our microarray analysis in Arabidopsis. The MYB108 ORF was amplified using PCR reaction incorporating A. thaliana cDNA as a template. The products were cloned into pDONR221 by Gateway BP clonase II Enzyme Mix (Invitrogen), subsequently fused to the GAL4 activation domain (AD) in the pGADT7 vector to create pGADT7-MYB108 by Gateway LR clonase II Enzyme Mix (Invitrogen). Around $1 \mathrm{~Kb}$ DNA fragments located upstream of the predicted transcription start site of ANAC003, ANAC010, ANAC042 and $A N A C 075$, respectively contain potential sequences binding to MYB. These promoter regions were amplified by PCR reactions using primers containing SacI and SpeI restriction sites and then cloned into the pHIS2.1 vector (Clontech) to generate recombinant constructs: pHIS2.1-ANAC003p, pHIS2.1-ANAC010p, pHIS2.1-ANAC042p and pHIS2.1-ANAC075p. Thereafter, pGADT7-MYB108 and pHIS2.1-ANAC003p (or pHIS2.1-ANAC010p, or pHIS2.1-ANAC042p, or pHIS2.1-ANAC075p) were co-transformed into yeast AH109 strain, followed by grown for three days on SD/-Leu/-Trp medium and SD/-Leu/-Trp/-His medium with or without $5 \mathrm{mM} 3-\mathrm{AT}$ to investigate the expression of the reporter gene HIS3. Plasmid pGADT7 alone was used as a negative control.

\section{Conclusions}

Tic55 is associated with several translocon proteins (such as Tic32, Tic62, Tic110, and Tic40) located at the IM of chloroplasts in peas, and functions as a chloroplast protein importer [18-20]. Of note, Tic55 executes its activity as a hydroxylase of phyllobilins during plant senescence in $A$. thaliana [22], however, the regulatory network remains unclear. The characterization of a tic55-II-knockout mutant, which generated neither tic55 mRNA nor protein, showed no significant phenotypic differences between WT and tic55-II-knockout $A$. thaliana, suggesting that Tic55 is not functionally essential for its survival. A unique biological function of Tic55 was finally revealed when A. thaliana was aged under dark treatment and the senescent leaves were analyzed using microarray technology. Based on microarray analysis results, seven senescence-associated genes (SAGs) were selected for qRT-PCR analysis. 
The results of qRT-PCR analysis correlated closely with those of microarray analysis, indicating the reliability of the microarray results (Figure 7). The absence of Tic55 in the tic55-II-knockout mutant indirectly inhibited the expression of these seven senescence-related genes, subsequently delaying leaf senescence. Our data thus indicate that the novel biological function of Tic 55 is related to the dark-induced aging of A. thaliana. This is supported by the results of Hauenstein et al. [22], who indicated that Tic55 functions as a hydroxylase and is involved in chlorophyll breakdown during plant senescence. However, their work mainly focuses on the elucidation of the biological function of Tic55, whereas our study reveals not only the direct effect of Tic55 on chlorophyll catabolism but also its indirect role in the downstream senescence associated genes ( $S A G s$ ) expression through microarray and qRT-PCR analyses. Furthermore, yeast one-hybrid assays confirmed the expression of the NAC gene, ANAC003, was likely controlled by MYB108, which was also downregulated in dark stressed tic55-II-knockout mutant. Our studies thus shed light on further understanding the biological function of chloroplast protein Tic55 and its association with MYB-NAC network signaling involved in the dark-induced aging, since researches regarding light-related senescence are relatively rare.

Supplementary Materials: Supplementary materials can be found at http://www.mdpi.com/1422-0067/19/7/ $1854 /$ s1.

Author Contributions: Conceptualization, M.-L.C. and L.-F.L.; Data curation, M.-L.C., W.-Y.L. and L.-F.L.; Formal analysis, M.-L.C., W.-Y.L., W.-C.W., A.Y.-S.L., C.-Y.C., C.-L.W., C.-L.L., T.-H.F. and L.-F.L.; Funding acquisition, M.-L.C. and L.-F.L.; Investigation, M.-L.C., C.-L.L., T.-H.F. and L.-F.L.; Methodology, M.-L.C., W.-Y.L. and L.-F.L.; Project administration, M.-L.C. and L.-F.L.; Resources, M.-L.C. and L.-F.L.; Software, M.-L.C., C.-L.L., T.-H.F. and L.-F.L.; Supervision, M.-L.C. and L.-F.L.; Validation, M.-L.C., W.-Y.L., W.-C.W., A.Y.-S.L., C.-Y.C., C.-L.W., C.-L.L., T.-H.F. and L.-F.L.; Visualization, M.-L.C., W.-Y.L., W.-C.W., A.Y.-S.L., C.-Y.C., C.-L.W. and L.-F.L.; Writing—original draft, L.-F.L.; Writing—review \& editing, M.-L.C. and L.-F.L. All authors have read and approved the final manuscript.

Funding: This work was supported in part by National Science Council, Taiwan (Grants No. NSC97-2311-B320-002-MY3 and MOST105-2313-B-320-003 to MLC) and Tzu Chi University, Taiwan (Grants No. TCMRC-P102005 to MLC and TCMRC-P-100008; TCMRC-P-102008 to LFL).

Acknowledgments: We are grateful to the ABRC for providing the SALK_086048 mutant seeds as well as to Hsou-min Li (Institute of Molecular Biology, Academia Sinica, Taipei, Taiwan) for gifting antiserum against Toc159, Tic110, Tic40, Tic55 and ClpC (Hsp93) and critiquing the manuscript. We acknowledge Wallace Academic Editing for editing this manuscript.

Conflicts of Interest: The authors declare no conflict of interest.

Abbreviations
$\begin{array}{ll}\text { Toc and Tic } & \text { Translocon at the outer/inner membrane of chloroplasts } \\ \text { IDLs } & \text { individually darkened leaves } \\ \text { ASP3 } & \text { aspartate aminotransferase 3 } \\ \text { APG7 } & \text { autophagy-related 7, ubiquitin-like modifier-activating enzyme ATG7 } \\ \text { DIN2 } & \text { dark inducible 2, beta-glucosidase 30 } \\ \text { DIN11 } & \text { dark inducible 11,2-oxoacid-dependent dioxygenase-like protein } \\ \text { SAG12 } & \text { senescence-associated gene 12, cysteine protease } \\ \text { SAG13 } & \text { senescence-associated gene 13, senescence-associated protein } \\ \text { YLS9 } & \text { yellow-leaf-specific gene 9, protein NDR1/HIN1-like 10 } \\ \text { ABRC } & \text { Arabidopsis Biological Resource Center } \\ \text { NBT } & \text { nitro blue tetrazolium } \\ \text { BCIP } & \text { bromochloroindoyl phosphate }\end{array}$




\section{References}

1. Chou, M.L.; Fitzpatric, L.M.; Tu, S.L.; Budziszewski, G.; Potter-Lewis, S.; Akita, M.; Levin, J.Z.; Keegstra, K.; Li, H.-M. Tic40, a membrane-anchored co-chaperone homolog in the chloroplast protein translocon. EMBO J. 2003, 22, 2970-2980. [CrossRef] [PubMed]

2. Inaba, T.; Li, M.; Alvarez-Huerta, M.; Kessler, F.; Schnell, D.J. atTic110 functions as a scaffold for coordinating the stromal events of protein import into chloroplasts. J. Biol. Chem. 2003, 278, 38617-38627. [CrossRef] [PubMed]

3. Chou, M.L.; Chu, C.C.; Chen, L.J.; Akita, M.; Li, H.M. Stimulation of transit-peptide release and ATP hydrolysis by a cochaperone during protein import into chloroplasts. J. Cell Biol. 2006, 175, 893-900. [CrossRef] [PubMed]

4. Benz, J.P.; Soll, J.; Bölter, B. Protein transport in organelles: The composition, function and regulation of the Tic complex in chloroplast protein import. FEBS J. 2009, 276, 1166-1176. [CrossRef] [PubMed]

5. Kikuchi, S.; Oishi, M.; Hirabayashi, Y.; Lee, D.W.; Hwang, I.; Nakai, M. A 1-megadalton translocation complex containing Tic20 and Tic21 mediates chloroplast protein import at the inner envelope membrane. Plant Cell 2009, 21, 1781-1797. [CrossRef] [PubMed]

6. Su, P.H.; Li, H.M. Stromal Hsp70 is important for protein translocation into pea and Arabidopsis chloroplasts. Plant Cell 2010, 22, 1516-1531. [CrossRef] [PubMed]

7. Inoue, H.; Li, M.; Schnell, D.J. An essential role for chloroplast heat shock protein 90 (Hsp90C) in protein import into chloroplasts. Proc. Natl. Acad. Sci. USA 2013, 110, 3173-3178. [CrossRef] [PubMed]

8. Bölter, B.; Soll, J.; Schwenkert, S. Redox meets protein trafficking. Biochim. Biophys. Acta 2015, 1847, 949-956. [CrossRef] [PubMed]

9. Nakai, M. The Tic complex uncovered: The alternative view on the molecular mechanism of protein translocation across the inner envelope membrane of chloroplasts. Biochim. Biophys. Acta 2015, 1847, 957-967. [CrossRef] [PubMed]

10. Li, H.M.; Chiu, C.C. Protein transport into chloroplasts. Annu. Rev. Plant Biol. 2010, 61, 157-180. [CrossRef] [PubMed]

11. Kovács-Bogdán, E.; Benz, J.P.; Soll, J.; Bölter, B. Tic20 forms a channel independent of Tic110 in chloroplasts. BMC Plant Biol. 2011, 11, 133-148. [CrossRef] [PubMed]

12. Kikuchi, S.; Bedard, J.; Hirano, M.; Hirabayashi, Y.; Oishi, M.; Imai, M.; Takase, M.; Ide, T.; Nakai, M. Uncovering the protein translocon at the chloroplast inner envelope membrane. Science 2013, 339, 571-574. [CrossRef] [PubMed]

13. Balsera, M.; Goetze, T.A.; Kovacs-Bogdan, E.; Schurmann, P.; Wagner, R.; Buchanan, B.B.; Soll, J.; Bölter, B. Characterization of Tic110, a channel-forming protein at the inner envelope membrane of chloroplasts, unveils a response to $\mathrm{Ca}^{2+}$ and a stromal regulatory disulfide bridge. J. Biol. Chem. 2009, 284, 2603-2616. [CrossRef] [PubMed]

14. Hirohashi, T.; Hase, T.; Nakai, M. Maize non-photosynthetic ferredoxin precursor is mis-sorted to the intermembrane space of chloroplasts in the presence of light. Plant Physiol. 2001, 125, 2154-2163. [CrossRef] [PubMed]

15. Stengel, A.; Benz, J.P.; Soll, J.; Bölter, B. Redox-regulation of protein import into chloroplasts and mitochondria: Similarities and differences. Plant Signal. Behav. 2010, 5, 105-109. [CrossRef] [PubMed]

16. Stengel, A.; Benz, J.P.; Balsera, M.; Soll, J.; Bölter, B. Tic62 redox-regulated translocon composition and dynamics. J. Biol. Chem. 2008, 283, 6656-6667. [CrossRef] [PubMed]

17. Chigri, F.; Hörmann, F.; Stamp, A.; Stammers, D.K.; Bölter, B.; Soll, J.; Vothknecht, U.C. Calcium regulation of chloroplast translocation is mediated by calmodulin binding to Tic32. Proc. Natl. Acad. Sci. USA 2006, 103, 16051-16056. [CrossRef] [PubMed]

18. Hormann, F.; Kuchler, M.; Sveshnikov, D.; Oppermann, U.; Li, Y.; Soll, J. Tic32, an essential component in chloroplast biogenesis. J. Biol. Chem. 2004, 279, 34756-34762. [CrossRef] [PubMed]

19. Bartsch, S.; Monnet, J.; Selbach, K.; Quigley, F.; Gray, J.; von Wettstein, D.; Reinbothe, S.; Reinbothe, C. Three thioredoxin targets in the inner envelope membrane of chloroplasts function in protein import and chlorophyll metabolism. Proc. Natl. Acad. Sci. USA 2008, 105, 4933-4938. [CrossRef] [PubMed] 
20. Benz, J.P.; Stengel, A.; Lintala, M.; Lee, Y.H.; Weber, A.; Philippar, K.; Gügel, I.L.; Kaieda, S.; Ikegami, T.; Mulo, P.; et al. Arabidopsis Tic62 and ferredoxin-NADP(H) oxidoreductase form light-regulated complexes that are integrated into the chloroplast redox poise. Plant Cell 2009, 21, 3965-3983. [CrossRef] [PubMed]

21. Boij, P.; Patel, R.; Garcia, C.; Jarvis, P.; Aronsson, H. In vivo studies on the roles of Tic55-related proteins in chloroplast protein import in Arabidopsis thaliana. Mol. Plant 2009, 2, 1397-1409. [CrossRef] [PubMed]

22. Hauenstein, M.; Christ, B.; Das, A.; Aubry, S.; Hörtensteiner, S. A Role for Tic55 as a hydroxylase of phyllobilins, the products of chlorophyll breakdown during plant senescence. Plant Cell 2016, 28, 2510-2527. [CrossRef] [PubMed]

23. Lim, P.O.; Woo, H.R.; Nam, H.G. Molecular genetics of leaf senescence in Arabidopsis. Trends Plant Sci. 2003, 8, 272-278. [CrossRef]

24. Huang, Y.; Li, T.; Xu, Z.S.; Wang, F.; Xiong, A.S. Six NAC transcription factors involved in response to TYLCV infection in resistant and susceptible tomato cultivars. Plant Physiol. Biochem. 2017, 120, 61-74. [CrossRef] [PubMed]

25. Lim, P.O.; Kim, H.J.; Nam, H.G. Leaf senescence. Annu. Rev. Plant Biol. 2007, 58, 115-136. [CrossRef] [PubMed]

26. Guo, Y.; Gan, S. Convergence and divergence in gene expression profiles induced by leaf senescence and 27 senescence-promoting hormonal, pathological and environmental stress treatments. Plant Cell Environ. 2012, 35, 644-655. [CrossRef] [PubMed]

27. Sakuraba, Y.; Jeong, J.; Kang, M.Y.; Kim, J.; Paek, N.C.; Choi, G. Phytochrome-interacting transcription factors PIF4 and PIF5 induce leaf senescence in Arabidopsis. Nat. Commun. 2014, 5, 4636-4648. [CrossRef] [PubMed]

28. Thomas, H.; Schellenberg, M.; Vicentini, F.; Matile, P. Gregor Mendel's green and yellow pea seeds Bot. Acta 1996, 109, 3-4.

29. Buchanan-Wollaston, V.; Earl, S.; Harrison, E.; Mathas, E.; Navabpour, S.; Page, T.; Pink, D. The molecular analysis of leaf senescence-A genomics approach. Plant Biotechnol. J. 2003, 1, 3-22. [CrossRef] [PubMed]

30. Kilian, J.; Whitehead, D.; Horak, J.; Wanke, D.; Weinl, S.; Batistic, O.; D’Angelo, C.; Bornberg-Bauer, E.; Kudla, J.; Harter, K. The AtGenExpress global stress expression data set: Protocols, evaluation and model data analysis of UV-B light, drought and cold stress responses. Plant J. 2007, 50, 347-363. [CrossRef] [PubMed]

31. Puranik, S.; Sahu, P.P.; Srivastava, P.S.; Prasad, M. NAC proteins: Regulation and role in stress tolerance. Trends Plant. Sci. 2012, 17, 369-381. [CrossRef] [PubMed]

32. Hickman, R.; Hill, C.; Penfold, C.A.; Breeze, E.; Bowden, L.; Moore, J.D.; Zhang, P.; Jackson, A.; Cooke, E.; Bewicke-Copley, F.; et al. A local regulatory network around three NAC transcription factors in stress responses and senescence in Arabidopsis leaves. Plant J. 2013, 75, 26-39. [CrossRef] [PubMed]

33. Ooka, H.; Satoh, K.; Doi, K.; Nagata, T.; Otomo, Y.; Murakami, K.; Matsubara, K.; Osato, N.; Kawai, J.; Carninci, P.; et al. Comprehensive analysis of NAC family genes in Oryza sativa and Arabidopsis thaliana. DNA Res. 2003, 10, 239-247. [CrossRef] [PubMed]

34. Fujita, M.; Fujita, Y.; Maruyama, K.; Seki, M.; Hiratsu, K.; Ohme-Takagi, M.; Tran, L.-S.P.; Yamaguchi-Shinozaki, K.; Shinozaki, K. A dehydration- induced NAC protein, RD26, is involved in a novel ABA-dependent stress-signaling pathway. Plant J. 2004, 39, 863-876. [CrossRef] [PubMed]

35. Tran, L.S.; Nakashima, K.; Sakuma, Y.; Simpson, S.D.; Fujita, Y.; Maruyama, K.; Fujita, M.; Seki, M.; Shinozaki, K.; Yamaguchi-Shinozaki, K. Isolation and functional analysis of Arabidopsis stress inducible NAC transcription factors that bind to a drought responsive cis-element in the early responsive to dehydration stress promoter. Plant Cell 2004, 16, 2481-2498. [CrossRef] [PubMed]

36. Guo, Y.; Gan, S. AtNAP, a NAC family transcription factor, has an important role in leaf senescence. Plant J. 2006, 46, 601-612. [CrossRef] [PubMed]

37. Hu, H.; Dai, M.; Yao, J.; Xiao, B.; Li, X.; Zhang, Q.; Xiong, L. Overexpressing a NAM, ATAF, and CUC (NAC) transcription factor enhances drought resistance and salt tolerance in rice. Proc. Natl. Acad. Sci. USA 2006, 103, 12987-12992. [CrossRef] [PubMed]

38. Balazadeh, S.; Siddiqui, H.; Allu, A.D.; Matallana-Ramirez, L.P.; Caldana, C.; Mehrnia, M.; Zanor, M.I.; Kohler, B.; Mueller-Roeber, B. A gene regulatory network controlled by the NAC transcription factor ANAC092/AtNAC2/ORE1 during salt-promoted senescence. Plant J. 2010, 62, 250-264. [CrossRef] [PubMed] 
39. Nakashima, K.; Takasaki, H.; Mizoi, J.; Shinozaki, K.; Yamaguchi-Shinozaki, K. NAC transcription factors in plant abiotic stress responses. Biochim. Biophys. Acta 2012, 1819, 97-103. [CrossRef] [PubMed]

40. Aida, M.; Ishida, T.; Fukaki, H.; Fujisawa, H.; Tasaka, M. Genes involved in organ separation in Arabidopsis: An analysis of the cup-shaped cotyledon mutant. Plant Cell 1997, 9, 841-857. [CrossRef] [PubMed]

41. Ernst, H.A.; Olsen, A.N.; Larsen, S.; Lo Leggio, L. Structure of the conserved domain of ANAC, a member of the NAC family of transcription factors. EMBO Rep. 2004, 5, 297-303. [CrossRef] [PubMed]

42. Jensen, M.K.; Kjaersgaard, T.; Nielsen, M.M.; Galberg, P.; Petersen, K.; O'Shea, C.; Skriver, K. The Arabidopsis thaliana NAC transcription factor family: Structure-function relationships and determinants of ANAC019 stress signalling. Biochem. J. 2010, 426, 183-196. [CrossRef] [PubMed]

43. Tran, L.S.; Nishiyama, R.; Yamaguchi-Shinozaki, K.; Shinozaki, K. Potential utilization of NAC transcription factors to enhance abiotic stress tolerance in plants by biotechnological approach. GM Crops 2010, 1, 32-39. [CrossRef] [PubMed]

44. Woo, H.R.; Kim, H.J.; Nam, H.G.; Lim, P.O. Plant leaf senescence and death-Regulation by multiple layers of control and implications for aging in general. J. Cell Sci. 2013, 126, 4823-4833. [CrossRef] [PubMed]

45. Kim, H.J.; Nam, H.G.; Lim, P.O. Regulatory network of NAC transcription factors in leaf senescence. Curr. Opin. Plant Biol. 2016, 33, 48-56. [CrossRef] [PubMed]

46. Breeze, E.; Harrison, E.; McHattie, S.; Hughes, L.; Hickman, R.; Hill, C.; Kiddle, S.; Kim, Y.S.; Penfold, C.A.; Jenkins, D.; et al. High-resolution temporal profiling of transcripts during Arabidopsis leaf senescence reveals a distinct chronology of processes and regulation. Plant Cell 2011, 23, 873-894. [CrossRef] [PubMed]

47. Penfold, C.A.; Buchanan-Wollaston, V. Modelling transcriptional networks in leaf senescence. J. Exp. Bot. 2014, 65, 3859-3873. [CrossRef] [PubMed]

48. Leibsch, D.; Keech, O. Dark-induced leaf senescence: New insights into a complex light-dependent regulatory pathway. New Phytol. 2016, 212, 563-570. [CrossRef] [PubMed]

49. Swarbreck, D.; Wilks, C.; Lamesch, P.; Berardini, T.Z.; Garcia-Hernandez, M.; Foerster, H.; Li, D.; Meyer, T.; Muller, R.; Ploetz, L.; et al. The Arabidopsis Information Resource (TAIR): Gene structure and function annotation. Nucleic Acids Res. 2008, 36, D1009-D1014. [CrossRef] [PubMed]

50. Lamesch, P.; Berardini, T.Z.; Li, D.; Swarbreck, D.; Wilks, C.; Sasidharan, R.; Muller, R.; Dreher, K.; Alexander, D.L.; Garcia-Hernandez, M.; et al. The Arabidopsis Information Resource (TAIR): Improved gene annotation and new tools. Nucleic Acids Res. 2012, 40, D1202-D1210. [CrossRef] [PubMed]

51. Schultz, C.J.; Coruzzi, G.M. The aspartate aminotransferase gene family of Arabidopsis encodes isoenzymes localized to three distinct subcellular compartments. Plant J. 1995, 7, 61-75. [CrossRef] [PubMed]

52. Miller, J.D.; Arteca, R.N.; Pell, E.J. Senescence-associated gene expression during ozone-induced leaf senescence in Arabidopsis. Plant Physiol. 1999, 120, 1015-1024. [CrossRef] [PubMed]

53. Noh, Y.S.; Amasino, R.M. Identification of a promoter region responsible for the senescence-specific expression of SAG12. Plant Mol. Biol. 1999, 41, 181-194. [CrossRef] [PubMed]

54. Fujiki, Y.; Yoshikawa, Y.; Sato, T.; Inada, N.; Ito, M.; Nishida, I.; Watanabe, A. Dark-inducible genes from Arabidopsis thaliana are associated with leaf senescence and repressed by sugars. Physiol. Plant 2001, 111, 345-352. [CrossRef] [PubMed]

55. Yoshida, S.; Ito, M.; Nishida, I.; Watanabe, A. Isolation and RNA gel blot analysis of genes that could serve as potential molecular markers for leaf senescence in Arabidopsis thaliana. Plant Cell Physiol. 2001, 42, 170-178. [CrossRef] [PubMed]

56. Doelling, J.H.; Walker, J.M.; Friedman, E.M.; Thompson, A.R.; Vierstra, R.D. The APG8/12-activating enzyme APG7 is required for proper nutrient recycling and senescence in Arabidopsis thaliana. J. Biol. Chem. 2002, 277, 33105-33114. [CrossRef] [PubMed]

57. Huynh, L.N.; Vantoai, T.; Streeter, J.; Banowetz, G. Regulation of flooding tolerance of SAG12:ipt Arabidopsis plants by cytokinin. J. Exp. Bot. 2005, 56, 1397-1407. [CrossRef] [PubMed]

58. Otegui, M.S.; Noh, Y.S.; Martínez, D.E.; Vila Petroff, M.G.; Staehelin, L.A.; Amasino, R.M.; Guiamet, J.J. Senescence-associated vacuoles with intense proteolytic activity develop in leaves of Arabidopsis and soybean. Plant J. 2005, 41, 831-844. [CrossRef] [PubMed]

59. Guo, Y.; Gan, S. Leaf senescence: Signals, execution, and regulation. Curr. Top. Dev. Biol. 2005, 71, 83-112. [PubMed] 
60. Inaba, T.; Alvarez-Huerta, M.; Li, M.; Bauer, J.; Ewers, C.; Kessler, F.; Schnell, D.J. Arabidopsis Tic110 is essential for the assembly and function of the protein import machinery of plastids. Plant Cell 2005, 17, 1482-1496. [CrossRef] [PubMed]

61. Caliebe, A.; Grimm, R.; Kaiser, G.; Lubeck, J.; Soll, J.; Heins, L. The chloroplastic protein import machinery contains a Rieske-type iron-sulfur cluster and a mononuclear iron-binding protein. EMBO J. 1997, 16, 7342-7350. [CrossRef] [PubMed]

62. Küchler, M.; Decker, S.; Hörmann, F.; Soll, J.; Heins, L. Protein import into chloroplasts involves redox-regulated proteins. EMBO J. 2002, 21, 6136-6145. [CrossRef] [PubMed]

63. Tanaka, R.; Hirashima, M.; Satoh, S.; Tanaka, A. The Arabidopsis-accelerated cell death gene ACD1 is involved in oxygenation of pheophorbide $a$ : Inhibition of the pheophorbide $a$ oxygenase activity does not lead to the "stay-green" phenotype in Arabidopsis. Plant Cell Physiol. 2003, 44, 1266-1274. [CrossRef] [PubMed]

64. Gray, J.; Close, P.S.; Briggs, S.P.; Johal, G.S. A novel suppressor of cell death in plants encoded by the Lls1 gene of maize. Cell 1997, 89, 25-31. [CrossRef]

65. Gray, J.; Wardzala, E.; Yang, M.; Reinbothe, S.; Haller, S.; Pauli, F. A small family of LLS1-related non-heme oxygenases in plants with an origin amongst oxygenic photosynthesizers. Plant Mol. Biol. 2004, 54, 39-54. [CrossRef] [PubMed]

66. Nakashima, K.; Ito, Y.; Yamaguchishinozaki, K. Transcriptional regulatory networks in response to abiotic stresses in Arabidopsis and grasses. Plant Physiol. 2009, 149, 88-95. [CrossRef] [PubMed]

67. Pontier, D.; Gan, S.; Amasino, R.M.; Roby, D.; Lam, E. Markers for hypersensitive response and senescence show distinct patterns of expression. Plant Mol. Biol. 1999, 39, 1243-1255. [CrossRef] [PubMed]

68. Bailey, T.L.; Boden, M.; Buske, F.A.; Frith, M.; Grant, C.E.; Clementi, L.; Ren, J.Y.; Li, W.W.; Noble, W.S. MEME SUITE: Tools for motif discovery and searching. Nucleic Acids Res. 2009, 37, W202-W208. [CrossRef] [PubMed]

69. Tamura, K.; Stecher, G.; Peterson, D.; Filipski, A.; Kumar, S. MEGA6: Molecular Evolutionary Genetics Analysis Version 6.0. Mol. Biol. Evol. 2013, 30, 2725-2729. [CrossRef] [PubMed]

70. Felsenstein, J. Confidence limits on phylogenies: An approach using the bootstrap. Evolution 1985, 39, 783-791. [CrossRef] [PubMed]

71. Saitou, N.; Nei, M. The neighbor-joining method: A new method for reconstructing phylogenetic trees. Mol. Biol. Evol. 1987, 4, 406-425. [PubMed]

72. Podzimska-Sroka, D.; O'Shea, C.; Gregersen, P.L.; Skriver, K. NAC transcription factors in senescence: From molecular structure to function in crops. Plants 2015, 4, 412-448. [CrossRef] [PubMed]

73. Fujita, M.; Fujita, Y.; Noutoshi, Y.; Takahashi, F.; Narusaka, Y.; Yamaquchi-Shinozaki, K.; Shinozaki, K. Crosstalk between abiotic and biotic stress responses: A current view from the points of convergence in the stress signaling networks. Curr. Opin. Plant Biol. 2006, 9, 436-442. [CrossRef] [PubMed]

74. Bu, Q.; Jiang, H.; Li, C.B.; Zhai, Q.; Zhang, J.; Wu, X.; Sun, J.; Xie, Q.; Li, C. Role of the Arabidopsis thaliana NAC transcription factors ANAC019 and ANAC055 in regulating jasmonic acid signaled defense responses. Cell Res. 2008, 18, 756-767. [CrossRef] [PubMed]

75. Solano, R.; Nieto, C.; Avila, J.; Canas, L.; Diaz, I.; Paz-Ares, J. Dual DNA binding specificity of a petal epidermis-specific MYB transcription factor (MYB.Ph3) from Petunia hybrid. EMBO J. 1995, 14, 1773-1784. [PubMed]

76. Mengiste, T.; Chen, X.; Salmeron, J.; Dietrich, R. The BOTRYTIS SUSCEPTIBLE 1 gene encodes an $\mathrm{R}_{2} \mathrm{R}_{3} \mathrm{MYB}$ transcription factor protein that is required for biotic and abiotic stress responses in Arabidopsis. Plant Cell 2003, 15, 2551-2565. [CrossRef] [PubMed]

77. Mandaokar, A.; Browse, J. MYB108 acts together with MYB24 to regulate jasmonate-mediated stamen maturation in Arabidopsis. Plant Physiol. 2009, 149, 851-862. [CrossRef] [PubMed]

78. Chow, C.N.; Zheng, H.Q.; Wu, N.Y.; Chien, C.H.; Huang, H.D.; Lee, T.Y.; Chiang-Hsieh, Y.F.; Hou, P.F.; Yang, T.Y.; Chang, W.C. PlantPAN 2.0: An update of plant promoter analysis navigator for reconstructing transcriptional regulatory networks in plants. Nucleic Acids Res. 2016, 44, 1154-1160. [CrossRef] [PubMed]

79. Budziszewski, G.J.; Lewis, S.P.; Glover, L.W.; Reineke, J.; Jones, G.; Ziemnik, L.S.; Lonowski, J.; Nyfeler, B.; Aux, G.; Zhou, Q.; et al. Arabidopsis genes essential for seedling viability: Isolation of insertional mutants and molecular cloning. Genetics 2001, 159, 1765-1778. [PubMed]

80. Aronsson, H.; Jarvis, P. A simple method for isolating import-competent Arabidopsis chloroplasts. FEBS Lett. 2002, 529, 215-220. [CrossRef] 
81. Waegemann, K.; Soll, J. Characterization of the protein import apparatus in isolated outer envelopes of chloroplasts. Plant J. 1991, 1, 149-158. [CrossRef]

82. Fitzpatrick, L.M.; Keegstra, K. A method for isolating a high yield of Arabidopsis chloroplasts capable of efficient import of precursor proteins. Plant J. 2001, 26, 59-66. [CrossRef]

83. Li, H.M.; Chen, L.J. Protein targeting and integration signal for the chloroplastic outer envelope membrane. Plant Cell 1996, 8, 2117-2126. [CrossRef] [PubMed]

84. Harlow, E.; Lane, D. Antibodies: A Laboratory Manual; Cold Spring Harbor Laboratory: Cold Spring Harbor, NY, USA, 1988.

85. Wada, S.; Ishida, H.; Izumi, M.; Yoshimoto, K.; Ohsumi, Y.; Mae, T.; Makino, A. Autophagy plays a role in chloroplast degradation during senescence in individually darkened leaves. Plant Physiol. 2008, 149, 885-893. [CrossRef] [PubMed]

86. Porra, R.J. The chequered history of the development and use of simultaneous equations for the accurate determination of chlorophylls $a$ and $b$. Photosynth. Res. 2002, 73, 149-156. [CrossRef] [PubMed]

87. Livak, K.J.; Schmittgen, T.D. Analysis of relative gene expression data using real-time quantitative PCR and the $2^{-\Delta \Delta C t}$ Method. Methods 2001, 25, 402-408. [CrossRef] [PubMed]

(C) 2018 by the authors. Licensee MDPI, Basel, Switzerland. This article is an open access article distributed under the terms and conditions of the Creative Commons Attribution (CC BY) license (http:/ / creativecommons.org/licenses/by/4.0/). 